\title{
The Devil of Delft in England
}

\section{The Reception of the Dutch Spiritualist David Joris in 17th-Century English Polemics}

Gary K. Waite | ORCID: 0000-0003-4417-0266

Department of History, University of New Brunswick, Fredericton, New Brunswick, Canada

waite@unb.ca

\begin{abstract}
The Dutch glasspainter and Anabaptist prophet David Joris (1501-1556) was the Netherland's most infamous heretic who became a spiritualist who depreciated the scriptures, condemned confessional conflict, and argued that the devil did not exist external to a person's mind. Unlike the Dutch founder of the Family of Love, Hendrik Niclaes, Joris had no following in England, yet English writers condemned him with increasing frequency over seventeenth century. This paper examines that response, showing that for most writers Joris was the exemplar of the dangers of visionary mysticism, while Catholics used him to condemn Protestantism in general. English writers remained largely unaware of Joris's denial of demons until ca. 1647, when they began to attack the idea, unintentionally publicizing it. Such polemical dissemination had decades earlier helped to calm fears of demonic witchcraft in the Dutch Republic; in England it may have also influenced the demonologies of some English nonconformists.
\end{abstract}

\section{Keywords}

David Joris - demonology - confessional polemics - spiritualism - Henry More nonconformists

\section{$1 \quad$ David Joris in England}

In the early 1520s, a young Dutch glasspainter, David Joris (1501-1556), travelled as a journeyman to England to work on a series of windows on the Passion of 
Christ for the Chapel of William Sandys, Henry viII's treasurer, in Basingstoke. ${ }^{1}$ Developing the designs in London, Joris became ill and returned home in 1524, setting up his own shop in Delft. He soon became a lay Evangelical activist decrying Catholic idolatry. For this he was arrested in 1528 and exiled for three years. By the time of his return to Holland in 1531, he had become captivated by the apocalyptical Anabaptism of Melchior Hoffman but was reluctant to take on any active role as Anabaptism became more militant in 1533 under Jan Matthijs's leadership and Münster became an Anabaptist city, then kingdomunder-siege. During the period of intense persecution in the year of Münster's fall in 1535, Joris sought refuge again in England, but a storm drove back his ship, and he never returned to the island. ${ }^{2}$ His journeyman tour proved to be his sole residency in England. He had no known following in the realm, nor were any of his writings known to be translated into English; so why would English writers use him over and over in their polemical publications through the late sixteenth and seventeenth centuries? This paper suggests several reasons for this fixation on a continental heretic on the part of English writers of all confessional stripes. First, Joris was perceived, in part correctly, as the major source of influence for the Anglo-Dutch spiritualistic group the Family of Love, and hence as the "arch-heretic" of extreme religious enthusiasm. While perhaps not fully appreciated by these writers, on the continent Joris's ideas were indeed influential, disseminated and discussed among various groups of religious nonconformists who sought new approaches to religion, both for individuals and for society. When new religious groups arose in England in the 1640s, many polemicists simply expanded the number of groups for which they blamed Joris. For both Protestant and Catholic polemicists, Joris became a role model of the dangers of relying on personal inspiration or visions uncontrolled by formal ecclesiastical oversight. Second, for Catholic writers Joris's controversial prophetic career as the messianic "third David" stood as a warning for how the spiritualizing tendencies within Protestantism in general would lead ultimately to atheism. Third, because they had no actual English works by Joris to read,

1 K.G. Boon, "De Glasschilder David Joris, een Exponent van het Doperse Geloof. Zijn Kunst en zijn Invloed op Dirck Crabeth," Mededelingen van de Koninklijke Academie voor Wetenschappen, Letteren en Schone Kunsten van België 64 (1988), 117-137, there 4.

2 Joris requires a new biography, but see Gary K. Waite, David Joris and Dutch Anabaptism, 1524-1543 (Waterloo, 1990); Roland Bainton, David Joris. Wiedertäufer und Kämpfer für Toleranz im 16. Jahrhundert (Leipzig, 1937); and Samme Zijlstra, Nicolaas Meyndertsz van Blesdijk. Een bijdrage tot de Geschiedenis van het Davidjorisme (Assen, 1983). On Joris's influence in the borderland region between the Netherlands and the Holy Roman Empire, see Karin Förster, Das reformatorische Täufertum in Oldenburg und Umgebung (1535-1540): Unter der besonderen Berücksichtigung des Täufertheologen David Joris (Berlin, 2019). 
polemical writers were unhindered by concerns over proper interpretation or rebuttals by supporters. Fourth, it appears that English writers were largely unaware of Joris's most controversial teaching denying the reality of demons (and angels) until just before 1650, and thereafter Joris became the poster child for the hidden agenda of unrestrained mysticism: to lead people to the denial of the supernatural, and hence to the atheism that proto-Enlightenment philosophers were beginning to promote.

Finally, the debate over Joris and his alleged teachings helps reveal how ideas were rethought not only among nonconformists pushing against orthodoxy, but also within networks of "orthodox" writers in reaction against such unlearned innovations. Some scholars of seventeenth-century English intellectual history, such as Dmitri Levitin, do not believe that those in the "radical' fringes" played any role in undermining orthodoxy, that instead "orthodox scholarship planted the seeds for its own undermining." ${ }^{3}$ While true in part, we will explore here how orthodox writers, consciously or not, reshaped their ideas in reaction to the unorthodox ideas of spiritualists like David Joris (George). This suggestion will be tested below when looking at the difference in the record of witch-hunting between the Dutch Republic, which ended trials early and never really adopted the full demonic stereotype, and England, which had a major panic in the 1640s. While Dutch writers had for a century been engaged in a debate over the reality of demons thanks to the notoriety of Joris's demonology, even the publication of Reginald Scots' The Discoverie of Witchcraft in 1584 did not inspire a serious engagement on the subject. On the basis of the works examined here, the idea that demons did not exist did not become a major part of English discourse until after the publication of a critical biography of Joris in 1642, the Life and Doctrine of the arch-heretic David Joris. ${ }^{4}$ The subject of shocked condemnation thereafter on the part of English and Scottish writers, Joris's heresy as expressed by polemicists may also have influenced the demonologies of various English nonconformists that suddenly appeared around $165^{\circ}$. While most of the evidence presented here is circumstantial, it needs to be considered as another possible factor in the divergent histories of the prosecution of demonic witchcraft in the Dutch Republic and England.

3 Dmitri Levitin, “'Radical' History Writing in 165os England: The Case of John Beale," in Radicalism and Dissent in the World of Protestant Reform, ed. Bridget Heal and Anorthe Kremers (Göttingen, 2017), 173-198, there 198.

4 Nicolaas Meyndertsz van Blesdijk, Historia vitae, doctrinae, ac rerum gestarum Davidis Georgii haeresiarchae (Deventer: Jacob Revius, 1642). 
Before turning to the polemical (mis)characterizations of Joris's ideas, it is important to rehearse something of Joris's known religious career. Joris survived the governmental crackdown on Anabaptist dissent by refusing to take on a leadership role, until finally in $\mathbf{1 5 3 6}$ he was persuaded to lead efforts to reunite the fractured movement at a meeting at Bocholt, Westphalia. Mediating between those who wanted to retain the militancy (and polygamy) of Münster and those who wanted pacifism and a saner approach to fellowship, Joris applied a deeply allegorical approach to scripture to forge a compromise among the attendees, all of whom thought their side had won. The agreement of course proved short-lived.

In the immediate aftermath of Bocholt, Joris, inspired by a close woman supporter, Anneke Jansdr of Rotterdam, experienced a series of dramatic visions that convinced him of his messianic role. This came crashing down, however, when on the eve of his revelation as the "third David" who would restore the kingdom of the godly slated for Christmas Day, 1538, governmental authorities arrested dozens of his supporters, torturing and executing most; among those killed was Joris's mother, Marietje Jan de Gortersdochter, who was beheaded on 21 February 1539 for defending her son. ${ }^{5}$ In the wake of this disillusioning experience, Joris abandoned any earthly fulfillment of scriptural prophecy, and instead moved quickly to spiritualism. In this he affirmed that the divine kingdom resided entirely within each believer who could achieve spiritual perfection and defeat the devil, death, and sin. For a few years Joris's group practiced public confession of sins wherein men and women stood naked in front of each other, and if there were no signs of sexual arousal, they were declared mature enough to marry. By 1540 Joris had abandoned his affiliation with Anabaptism, depreciated sacraments, ritual, dogma and the letter of scripture, and internalized all supernatural forces, including demons and angels, to the conscience of humans. ${ }^{6}$

5 See Willem de Bakker and Gary K. Waite, "Rethinking the Murky World of the Post-Münster Dutch Anabaptist Movement, 1535-1538: A Dialogue between Willem de Bakker and Gary K. Waite," Mennonite Quarterly Review 92 (2018), 47-91; and Waite, David Joris (see above, n. 2), 73 .

6 On Joris's demonology, see Gary K. Waite, “'Man is a Devil to Himself': David Joris and the Rise of a Sceptical Tradition towards the Devil in the Early Modern Netherlands, 1540-160o," Nederlands Archief voor Kerkgeschiedenis / Dutch Review of Church History, 75 (1995), 1-30, and "Knowing the Spirit(s) in the Dutch Radical Reformation: From Physical Perception to Rational Doubt, 1536-169o," in Knowing Demons, Knowing Spirits in the Early Modern Period 


\section{Joris's Reception in the Netherlands}

In 1539Joris, his wife and children found refuge in a noble manor near Antwerp, and in 1544 he and his wealthy noble patrons fled to Basel, Switzerland, where Joris, under the pseudonym Johann van Brugge (John of Bruges), lived in luxury until his death in $1556 .{ }^{7}$ In 1559 the city magistrates were forced to acknowledge that the Netherlandic gentleman was none other than the infamous heretic David Joris, and they conducted a trial, dug up his corpse, tied it to a stake, and burned it and many of his books and pictures to ashes.

This did not, however, end the story. Joris had written over 240 tracts, treatises, spiritual songs, dialogues, collections of letters, and large books, in particular The Wonder Book (c. 1543 and 1551), that were published and reprinted well into the seventeenth century, although only a few were translated into Latin or French. ${ }^{8}$ Joris's works were read widely in the Netherlands, by both those who supported his spiritualism and pleas for religious toleration, and by his many orthodox opponents - Reformed, Lutheran, Catholic, and Mennonitewho abhorred his depreciation of the letter of scripture in favour of the Spirit within and his criticism of formal learning. They feared his ideas would lead only to libertinism. By 160o, Joris had become a byword for spiritualist enthusiasm, prophetic pretensions verging on narcissism, and atheism for his denial of the independent existence of demons. His unusual sexual ethic also coloured his image.

In Dutch polemics, however, many writers took the effort to read Joris's works. There were some voices who proudly defended his ideas, and even after printers stopped production of his writings by the $163 \mathrm{os}$, others began to include them in collections of spiritualist works, most famously in the Impartial Church and Heresy History by the German Pietist Gottfried Arnold of 1700, and the Dutch mystic Michiel Vinke's The Silver Ark, which came out in $1723 .{ }^{9}$

(ca. 1400-1750), ed. Michelle D. Brock, Richard Raiswell, and David R. Winter (Basingstoke, 2018), 23-54.

7 The name was not, it seems, a fiction, as Joris's baptismal name was John, and he may have been born in Bruges. Waite, David Joris (see above, n. 2), 49.

8 Paul Valkema Blouw, "Printers to the 'Arch-Heretic' David Joris: Prolegomena to a Bibliography of His Works," Quarendo 21 (1991), 163-209; A. Van der Linde, David Joris. Bibliografie (The Hague, 1867). More works not cited by Van der Linde have been recently uncovered.

9 Gottfried Arnold, Unpartheiische Kirchen- und Ketzer Historie, 2 vols (Frankfurt, 1729; repr., Hildesheim, 1967); Michiel Vinke, De zilvere arke, bestaande in Geestelyke Gezangen, Stichtelyke Rymen en Historie-Liederen; met Aanteekeningen op dezelve Gepast. Vit verscheide Autheuren tot stichtinge byeen gebragt (Haarlem: Izaak Enschede, 1723), 269-311. See also Piet Visser, "'Blasphemous and Pernicious': the role of printers and booksellers in the spread of dissident 
Many who published against him, such as the Catholic spiritualist Dirck Volckertsz Coornhert and the conservative Mennonite Pieter Jansz Twisck, were at the same time positively influenced by their reading of Joris. ${ }^{10}$ After his death, readers could, if they wished, separate Joris's noxious reputation from his very interesting ideas about religious identity, the supremacy of internal spiritual piety over confessional externals, and religious toleration. His internalizing of demons and angels and removal of them from the natural world may not have been original to him, but Joris was the first to publish the idea in the vernacular starting in 1539/40, and his name became attached to it thereafter; for this he was nicknamed by some "the Devil of Delft." Joris's unconventional approach to the devil may also have been shaped by the internalizing motif of the drama of the Chambers of Rhetoric, for Joris composed songs and dialogues in their style, and his father, the merchant Joris van Amersfoort, seems to have been an actor who played the role of King David in one of the performances of these chambers. ${ }^{11}$ In their plays, rhetoricians transformed the character of the Devil into individual Vices, disposing Dutch viewers to imagine Satan as something other than a real external being. ${ }^{12}$ Internalizing supernatural beings such as demons and angels was also a natural development of the spiritualist dynamic, so those who espoused it did not necessarily have to have read Joris. This unconventional approach became popular in certain quarters in the Dutch Republic, where it helped shape opposition to witch-hunting, which the Dutch government, influenced by a pair of spiritualistic professors, ended much earlier than other realms. ${ }^{13}$ This meant, of

religious and philosophical ideas in the Netherlands in the second half of the seventeenth century," Quaerendo 26 (1996), 303-326, there 309, n. 2 o.

10 See Mirjam van Veen, "Spiritualism in the Netherlands: From David Joris to Dirck Volckertsz Coornhert," Sixteenth Century Journal 33 (2002), 129-150; Gary K. Waite, "Pieter Jansz Twisck on David Joris: A Conservative Mennonite and an Unconventional Spiritualist," Mennonite Quarterly Review 91 (2017), 371-402; and Gary K. Waite, "Martyrs and Nicodemites Both? Spiritualistic and Rationalistic Currents within the Dutch Anabaptist Tradition-David Joris, Sebastian Castellio, and Pieter Jansz Twisck 1535-1648," in Sebastian Castellio (1515-1563) —Dissidenz Und Toleranz: Beitrage Zu Einer Internationalen Tagung Auf Dem Monte Verita in Ascona 2015 [Refo5oo Academic Studies], ed. Barbara Mahlman-Bauer (Göttingen, 2018), 423-457. I have decided not to capitalize "spiritualist" to avoid implying that it was a formal confessional group, like Reformed, Catholic, etc. Instead, it was an approach to religious identity that prioritized the interior faith over externals and found a home in all denominations.

11 Waite, David Joris (see above, n. 3), 49.

12 Marcel Ficheroux, "Van helse intrigant tot toneelfiguur: De duivel op het toneel in de late Middeleeuwen (1400-16oo)," Trajecta 8 (1999), 3-30. See also Gary K. Waite, "Drama, Dutch," in Encylopedia of Witchcraft: the Western Tradition, ed. Richard Golden, 4 vols. (Santa Barbara, CA, 2006), 1: 291-294.

13 Hans de Waardt: "Netherlands, Northern," in Golden, Encyclopedia of Witchcraft (see 
course, that defenders of traditional demonology fought very hard against such blasphemy, and Joris's name and writings were heavily utilized in the 169 os in the debate over the controversial The Bewitched World by the Reformed Cartesian preacher Balthasar Bekker that denied demons a place in the natural world. ${ }^{14}$ When challenged, Bekker however admitted to being influenced by the books of several spiritualistic writers-Johan Wier's De praestigiis daemonum of ${ }_{1563}$, Reginald Scot's Discoverie of Witchcraft of 1584, and the skeptical treatises of liberal Mennonite (Doopsgezind) writers Jan Jansz Deutel (d. 1657), Abraham Palingh (d. 1682), and especially Antonius van Dale (d. 1708), whose work he deeply admired. ${ }^{15}$ While none of these Doopsgezind writers explicitly denied the devil a place in the natural world, their emphasis on the impotence of demons and of witchcraft reflected the Joristic demonology, albeit expressed more carefully than by Joris. The idea that demons may not exist in the natural world had become a familiar one in the Dutch Republic, reducing fear of demonic witchcraft, at least among elites. Dutch and German anti-Joris polemicists were very well-informed, and several cited from Joris's works.

Such was not the case in England. There is no natural reason why David Joris would have been a subject there at all. None of his writings are known to have been translated into English until the 2oth century. He had no known followers or supporters there, no known movement, no interested printers, no one to disseminate his ideas. English polemicists also had their hands full with the Family of Love, the spiritualistic group founded by the Dutch contemporary of Joris, Hendrik Niclaes. Niclaes's works were translated into English and printed mostly on the continent, and these helped develop and disseminate spiritualistic ideas in England that climaxed with the surge of new religious groups-Ranters, Levellers, Seekers, and Quakers—in the 164 os and 165 os. $^{16}$

above, n. 13), 3: 810-813, there 812, and Toverij en samenleving. Holland 1500-1800 (The Hague, 1991).

14 On the Bekker controversy, see Andrew C. Fix, Fallen Angels: Balthasar Bekker, Spirit Belief, and Confessionalism in the Seventeenth Century Dutch Republic (Dordrecht, 1999); and Jonathan Israel, Radical Enlightenment: Philosophy and the Making of Modernity, 1650-1750 (Oxford, 2001), 375-388.

15 See Waite, "Knowing the Spirit(s)" (see above, n. 6).

16 See, for example, David R. Como, "The Family of Love and the Making of English Revolutionary Religion: The Confession and 'Conversions' of Giles Creech," Journal of Medieval and Early Modern Studies 48 (2018), 553-598; David R. Como, Blown by the Spirit: Puri- 
For obvious reasons Niclaes is the most heavily cited and opposed heretic in English polemics, but that is natural given the major role his movement played in English nonconformist circles. In these decades there was also interest in translating and printing the works of other continental spiritualists, such as the spiritual alchemist Jacob Boehme. ${ }^{17}$ Yet, no one thought to translate Joris. It is well known that Niclaes borrowed heavily from Joris's ideas and writings, without, of course, acknowledging such. This is one matter that English polemicists perceived correctly, frequently asserting that David George was Niclaes's "Schoole-maister,"18 or that David George laid the egg that Hendrik Niclaes hatched. But, they did not need to spend much time on George at all, if English readers had little to no awareness of him.

Yet, they did. In 1578 and 1579 the Protestant writer John Rogers composed a tract against Niclaes; this was, of course, one of many produced by opponents of the small Familist groups. The poet Stephen Bateman prefaces Rogers's work by placing Niclaes within the long history of heretical idolaters from the Pharisees and Sadducees of the Gospels to ancient sects, such as the Arians, and of course to the papist tyranny. This was followed by the more contemporary "Anabaptists, Libertines, and diuers others" from which has proceeded a "comorant foule, the familie of loue, an hereticall sect, that hath to bring forth

tanism and the Emergence of an Antinomian Underground in Pre-Civil-War England (Stanford, 2004); and Peter Lake, The Boxmaker's Revenge: "Orthodoxy", "Heterodoxy" and the Politics of the Parish in Early Stuart London (Manchester, 2009). On tolerance in England, see Alexandra Walsham, Charitable Hatred:Tolerance and Intolerance in England ${ }_{1500-1700}$ (Manchester, 2006).

17 See, for example, The Tree of Christian Faith:Being a True Information, how a Man may be one Spirit with God, and what man must do to perform the works of God: In which is comprehended (compendiously) the whole Christian Doctrine and Faith. ... (London: John Macock, 1644); A description of the three principles of the divine essence viz., of the un-originall eternall birth of the Holy Trinity of God ... what the anger of God, sinne, death the Devill, and hell are ... (London: for H. Blunden, 1648); Mercurius Teutonicus, or A Christian Information concerning the last Times. Being Divers Propheticall Passages of the Fall of Babel, and the New Building in Zion. Gathered out of the Mysticall Writings of that famous Germane Author, Jacob Behmen, alias Teutonicus Phylosophus (London: for H. Blunden, 1649); and The Epistles of Jacob Behmen aliter, Tevtonicvs Philosophvs. Very usefull and necessary for those that read his Writings, and are very full of excellent and plaine Instructions how to attaine to The Life of Christ (London: for Gyles Calvert, 1649). On spiritual alchemy, see Mike A. Zuber, Spiritual Alchemy from the Age of Jacob Boehme to Mary Anne Atwood, 1600-1900, PhD dissertation, University of Amsterdam (2017).

18 John Knewstub, A confutation of monstrous and horrible heresies, taught by H.N. and embraced of a number, who call themselues the familie of loue by I. knewstub (London, for Richard Sergier, 1579), fol. $7^{\mathrm{v}}$. This is number 10 in Table 1; further references listed in the Table will be indicated as [Table 10], etc. 
a new puritie in religion." Bateman fears that unless the sovereign authorities step in to stop this "plague," that it will lead to a "newe persecution," presumably of Protestants, and to the murderous anarchy of Anabaptist Münster, led, he asserts, by "Dauid George, John a Leede, Knipper Dolling," and the fruit of which was Niclaes and his English followers. ${ }^{19}$ By thus associating Joris with the Münsterite king Jan van Leiden and his associate Bernt Knipperdolling, Bateman and Rogers, and indeed most other polemicists, could simply bypass detailed discussions of these militant Anabaptist leaders and move directly to Joris and Niclaes. Rogers does this quite explicitly, for as soon as Bateman's foreword is completed, he launches immediately into an extensive overview of the life of David George as a lead-in to that of Niclaes. ${ }^{20}$

Other writers did similarly; in 1579 the learned Anglican William Wilkinson wrote his own attack on the Familists, acknowledging his debt to Rogers and to the Swiss Reformer Heinrich Bullinger. Since Rogers had "enlinketh" Niclaes with "John a Leyde, and the Archheretique Dauid George to haue been confederates in spreading the heresie of the Anabaptistes at Munster," Wilkinson could therefore simply focus on George as Niclaes's mentor, esp. since Bullinger had identified the Joris sect as "the most pestilent of all others."21 Apart from the major English works on heresy, such as Ephraim Pagitt's famed Heresiography of 1645 , this was the standard approach; the Catholic writer William Rainolds, for example, mentioned Anabaptists several times, but not Münster, nor any other of its infamous leaders apart from Joris. ${ }^{22}$ In fact, over the course of the 17th century, references to David George not only increased in frequency in the polemical literature, but also in depth. Thanks to the text searchable function of Early English Books Online, my research assistant, Andrew Taber and I collected the known references to Joris in English publications from c. 1560 to c. 1700 . From the Basel pamphlet about Joris's post-mortem trial printed in 156o to the last citations in 1700 , there were 139 works that attacked Joris, while

19 [John Rogers], The Displaying of an horrible secte of grosse and wicked Heretiques, naming themselues the Familie of Love, with the liues of their Authours, and what doctrine they teach in corners. ... annexed a confession of certain articles made by 2 Family of Love, May 281561 ... (London: for George Bishop, 1579) [Table 8, 9], fols. Avv-Aviiiv.

$20 \quad$ Ibid., fols. Bi ${ }^{\mathrm{r}}$-Biij .

21 W. Wilkinson, A confutation of certaine articles deliuered vnto the familye of loue with the exposition of theophilus, a supposed elder in the sayd familye vpon the same articles.... (London: John Daye, 1579) [Table 11], 23-27, 75-76.

22 William Rainolds, A refutation of sundry reprehensions, cauils, and false sleightes, by which M. Whitaker laboureth to deface the late English translation, and Catholike annotations of the new Testament, and the booke of Discouery of heretical corruptions (Paris: [for Richard Verstegen?], 1583) [Table 13], 66-67. 
only a couple, both after 1673 , defended him in any way. This polemical critique came to a climax in the 1640 os and 165 os with the fluorescence of new religious groups in England (see Table 1).

Close examination of the most important of these polemical works has revealed many things, foremost among them is that English writers had, in contrast to their Dutch coreligionists, very few sources upon which to rely for their information on Joris. Research into the treatment of Joris by Dutch writers has revealed that their knowledge of Joris's unusual ideas, particularly his demonology, was extensive. ${ }^{23}$ They also knew much more about his controversial life and reputation, using this to tarnish any who might be tempted to cite his many publications. Even so, many readers of his works appreciated his strong defense of religious toleration and his depreciation of an independent devil. Some defenders explicitly used Joris's demonology to argue against witch-hunting. The orthodox thus worked very hard to condemn Joris's ideas precisely because they knew how pernicious they were to traditional beliefs, how they could become a staging post to theological and philosophical skepticism and even atheism. At the same time, Joris's demonology flowed through the various spiritualistic groups, including the Family of Love, some of the Dutch Remonstrants (Reformed opponents of Calvinism), and especially the liberal wings of the Mennonites, the Doopsgezinden.

\section{5}

The Basel Pamphlet and Catholic Interpretations of Joris

The English had their own preoccupations that shaped their discourse. They wrote as Anglicans against all forms of religious dissidence, or as Puritans fighting a two-way battle against episcopacy and Catholicism on the one side and sectarianism on the other, or as Catholics seeking to discredit Protestantism in general. Each side therefore developed the arguments about Joris that best suited their desired conclusions. Yet, they all suffered from the lack of access to the Dutch works that had the most accurate information about Joris, especially his own writings. I did not find a single English writer who had read any of the Joris corpus. Instead, the vast majority of writers relied heavily upon the pamphlet written in Latin for the city of Basel by its law professor, Johann Jeuchdenhammer (Sphyractes) in 1559, and translated into English and other languages in 156o, describing the post-mortem discovery of Joris's true identity and the confessions about his teaching that the court extracted from his family

23 See Waite, "Knowing the Spirit(s)" (see above, n. 6). 
and friends. ${ }^{24}$ This pamphlet informed virtually all of the pre-1640 publications referencing Joris, although it appears that many polemicists cited it only second hand, hence the stories told about Joris became increasingly extreme, as shall be seen here. Those who used the Basel pamphlet first and most frequently were Catholic writers seeking to present Joris as an erstwhile sincere Protestant who merely took Protestant theology to its logical conclusion, becoming in the end an apostate. The most frequently quoted section was that summarizing Joris's chief error:

For to conclude his errour he doth saye/ yf so be that Christes and his Apostles doctrine/ had ben the true churche/ it had not ben destroyed agayne/ as Christ doth saye hym selfe/ that agaynste the true churche the gates of Hell shall not preuale/ wherby he doth saye/ that it is well knowen that Antichrist hath rooted out/ the doctrine of Christ/ and his Aposteles/ whyche he doth mean by the Pope/ \& the Sea of Rome/ so that his whole meaning is/ that the doctrine of Christ \& his Aposteles is not sufficient/ but that onely the doctrine is sufficient/ which Dauid Gorge doth bringe to knowledge. ${ }^{25}$

In other words, Joris portrayed himself as the messianic successor to Jesus because he, like other Protestants, viewed the post-apostolic church as imperfect, hence in need of reform that only a divinely chosen agent could complete. $^{26}$

This was the argument cited by the Catholic William Rainolds in a massive tome published in 1583 attacking the Anglican William Whitaker, over the

24 Johann Sphyractes (Jeuchdenhammer), David Gorge, born in Holland, a very blasphemer of our messias Iesu Christ: of his lyfe and damnable heresi, now come to light, thre years after his death, in the year of our Lorde M.D. LIX. / Set forth by the reverendt father in God, Gouenor of the Vniversite of the cytie of Basel throwe the desyre of the honorable counsell of the same cytie, for to warne all good people from such abominable poyson, and now newly translated out of Latyne into Englysche (Basel: Conradus Mense, 1560) [Table 1]. Interestingly, the Cambridge University Library Rare Books copy, Syn.6.56.6, is heavily used, and only two partial pages survive. The Latin edition was also widely cited: Davidis Georgii Holandi Haeresiarchae uita \& Doctrina. Quandiu Basiliae fuit: tum quid post eius mortem, cum cadauere, libris, ac reliqua eius familia actum sit ... (Basel: Hyeronymi Curionis, 1559).

25 Sphyractes, David Gorge, born in Holland (see above, n. 24), fols. Diij —Diiijr.

26 Joris's belief that he was the "third David" who would complete the messianic mission was strongest between 1536 and 1539; by the time of the first edition of the Twonder Boeck (c. 1542/3), it is presented only in very obscure terms, while in the second edition of 1551 (printed in the 1580 ) he argues that the "third David" is the Holy Spirit within each believer. Waite, David Joris (see above, n. 2), 183-184. 
accusation that the pope was the Antichrist. ${ }^{27}$ Rainolds argues that the history of religion had degenerated from Lutheranism to Zwinglianism to Puritanism, which was "the very next degree to Anabaptisme" which in England took the form of the Family of Love, "a mere abnegation of Christianitie" with their "swarmes of Atheistes." 28 To counter Whitaker's claim that the Catholic Church had fallen, Rainolds brought up the case of David George the Hollander. His account of Joris's religious career thus emphasizes his Protestant credentials, as he has Joris expelled from the Low Countries for the "Sacramentarie heresie," which is to say for his early association with the Netherlandic Evangelicals who denied the Real Presence. Rainolds says nothing about Joris's Anabaptist stage, but suggests instead that he was supported by the citizens of Basel since they were of the same religion. It was in this Protestant city that Joris took on the office of Christ, disdaining Jesus as a deceiver. Since Basel's magistrates supported him, it was only after Joris's death that they were compelled to take action against the prophet's corpse. Why had Joris gone to this extreme of what Rainolds calls "Turkish madness"? Relying on the Basel pamphlet, Rainolds concludes that if Christ had been the true messiah, then the church he erected should have lasted forever. Hence, the Protestant argument that the universal church had fallen and needed to be restored led not to true reform, but to the atheism of Joris and the skepticism of Sebastian Castellio, the learned humanist of Basel. ${ }^{29}$ Whitaker's response was simply to affirm that Joris was a damnable heretic condemned by Protestants and Catholics alike, while Castellio did not deserve the slanders heaped upon him by Rainolds. ${ }^{30}$ By painting this distorted image of Joris, Rainolds believed he could discredit the entire Protestant movement; this could only be the case if Rainolds believed that his English readers would already know of Joris's negative reputation.

Rainolds's work was not the first by a Catholic author to use Joris in this way; in 1565 a Latin work by the German counsellor to Emperor Ferdinand, Fridericus Staphylus, was translated into English by Thomas Stapleton, critiquing the Protestant translation of the Bible in the "vulgar tongue." His portrayal of the Joris reputation is less developed than Rainolds', merely condemning the Calvinist's "schismatical communion" for their rejection of the Mass as "Juish

27 Rainolds, A refutation (see above, n. 22). Rogers, The Displaying of an horrible secte (see above, n. 2o) had earlier also used the Basel pamphlet.

28 Rainolds, $A$ refutation (see above, n. 22), 22.

29 Ibid., 66-67. Rainolds does not explicitly connect Joris and Castellio, but the two were friends.

$30 \quad$ William Whitaker, An answere to a certeine booke, written by M. William Rainolds Student of Diuinitie in the English colledge at Rhemes, and Entituled, A Refutation of sundrie reprehensions, cauils, etc. ... (London: Thomas Thomas, 1585) [Table 14], 36-37. 
superstition." For the Reformed to deny that the apostolic church was originally Catholic and the true church of Christ, "they may as wel denie Christ him selfe head thereof, and frustrat the whole, mistery of his blessed Incarnation, as you heard before Dauid George did," followed, Staphylus claims, by many Lutherans and Calvinists now across Germany. ${ }^{31}$

Another early Catholic use of Joris was that by J. Martiall who in 1566 wrote against a Protestant author, M. Calfhill, condemning the latter's iconoclasm. Martiall argued that Protestants were merely following the Jews and Turks who "detest the crosse as a signe of malediction." Calfhill allegedly abhorred the Catholic crucifix as "a magicall inchauntement, as a sorcerous mace, and as a signe of conquest against the Christians." If these Protestants do not "staye the rage of heresie," they will follow what David George began, "the Trinitaries, Anabaptistes, and such as circumcide them selues." Against Calfhill's claim that since evil people use the sign of the cross it is thus powerless, Martiall counters by saying no, "vnlesse he [Calfhill] were a younge God, or nere Cosyn to Dauid George that would be Christe." ${ }^{32}$ In the 1560 os, then, Joris's messianic pretensions were known well enough in England to be used by Catholic writers as a weapon against their Protestant rivals.

This tactic was referenced also by the Anglican bishop John Jewel in his critique of the Puritans in 1567 , and in a translation of a Danish work by the Lutheran theologian Niels Hemmingsen on the gospels two years later. For his part Hemmingsen simply warns his readers of prophetic claims, using as an example what happened a few years before in Germany when a certain Hollander, David George, took it upon himself to be Christ, deceiving many, until his corpse was dug up and burned. ${ }^{33}$ Jewel's argument is not unlike that of the Catholics, for he attempts a guilt by association between the Calvinists and Joris:

But what was Michael Seruetus the Arian, who was burnte at Geneua by procurement of Caluine, a Brother of yours? Dauid George that tooke vpon him to be Christe, who was taken vp after he was buried and burnte

$31 \quad$ Fridericus Staphylus, The apologie of Fridericus Staphylus counseller to the late Emperour Ferdinandus, \&c. Intreating of the true and right vnderstanding of holy Scripture. ... (Antwerp: John Latius, 1565) [Table 3], 247-248.

32 John Martiall, A replie to M. Calfhills blasphemous answer made against the Treatise of the crosse (Louvain: John Bogard, 1566) [Table 4], fol. *****iiijr.

33 Niels Hemmingsen, A Postill, or, Exposition of the Gospels that are usually red in the churches of God, vpon the Sundayes and feast dayes of Saincts written by Nicholas Hemminge a Dane, a Preacher of the Gospell, in the Vniuersitie of Hafnie ... (London: Henry Bynneman, 1569) [Table 6], fol. $316^{\mathrm{v}}$. 
at Basile, was he your Brother? To come neare home, Ioan of Kent that filth, who tooke foorthe a lesson further then you taught her (I trowe) or yet Preache, was she a Sister of yours? So many Adamites, so many Zwenckfeldians, so many hundreds of Anabaptistes and Libertines, as haue within your twentie yeeres benne ridde out of their liues by fiere, swoorde, and water in sundry partes of Christendome, were they al of your blessed Brotherhed? ${ }^{34}$

As for David George and Servetus the Arian, he continues, "they were yours, M. Hardinge, they were not of us." ${ }^{35}$ In the 1560 , then, Catholic, Lutheran, and Anglican writers used Joris's messianic claims and Servetus's denial of the Trinity to attack the Calvinists in particular.

Rainold's more extensive argument proved popular among Catholic writers and was replicated in various forms many times over the sixteenth and seventeenth centuries, some through translations of French works. These included three works by the Jesuit Lawrence Anderton (1577-1643), the first of which, under the pseudonym J.B. (John Brerely), appeared in 1604, and follows Rainold's argument, although Anderton uses the Latin edition of the Basel pamphlet. The dangers of Protestantism, he tells his reader, are apparent in the example of David George the Hollander, "who for many yeeres continued at Basill professing there the Protestants religion, and by them well estemed of till in the end he became a most blasphemous Apostata: and affirming our Sauiour to be a Seducer," arguing that if Christ had been perfect the Church would not have fallen. ${ }^{36}$ Such scruples also led Castellio to "doubtfull speaches of our Christian faith, and David George to plaine Apostasie."37

In his second work referencing Joris from 1633, Anderton follows an intriguing argument, suggesting that Protestantism is not a real thing, only a Platonic

34 John Jewel, A defence of the Apologie of the Churche of Englande conteininge an answeare to a certaine booke lately set foorthe by $M$. Hardinge, and entituled, A confutation of \&c. (London: Henry Wykes, 1567) [Table 5], 29. The Schwenckfeldians were followers of the influential Silesian spiritualist Caspar Schwenckfeld (1490-1561), who corresponded with Joris.

35 Ibid., 3 .

36 Lawrence Anderton, The apologie of the Romane Church deuided into three seuerall tractes whereof 1 . The first, concerneth the antiquitie and continuance of the Catholike Romane religion ever since the Apostles time. 2. The second that the Protestantes religion was not so much as in being, at or before Luthers first appearing. 3. The thirde that Catholickes are no lesse loyall and dutifull to their soveraigne, then Protestantes. All which are vndertaken and proued by testimonies of the learned Protestantes themselues (England: English secret press, 1604) [Table 19], 86.

Ibid., 9o. 
ideal, and hence nothing. It necessarily leads to the apostasy of a Joris and anti-trinitarianism, to becoming "most blasphemous Iewes, or Turkes; so true it is, that Turcisme, and Iudaisme is the last colour, dye, or tincture, that Protestancy taketh." Joris was, again, a "markable Protestant, and once Professour at Basill" who eventually wholly denied the Christian faith, becoming "a diuellish Apostata," just as the Lithuanian Calvinist theologian Andreas Volanus became a Turke. Not only has Anderton promoted Joris to a university professor, but he has depicted Volanus as a Muslim, even though he was in fact a major opponent of Fausto Sozzini, founder of the anti-trinitarian Socinians. ${ }^{38}$ Anderton expands on his argument in The progenie of Catholicks and Protestants, seeking to prove that only the Catholic faith has a lineage back to the apostles. Adding to the story of Joris's apostasy, Anderton cites the example of Bernardino Ochino (1487-1564), a former Capuchin friar who converted to Calvinism and who between 1547 and 1553 lived in England. Anderton notes that Ochino also became a freethinker speculating about the trinity and the validity of polygamy, and thus was condemned by both sides; Anderton has Ochino following Joris's rationale in his rejection of Catholicism. Anderton thus associates Joris with English Protestants, as well as with Sebastian Castellio. ${ }^{39}$ Other Catholic polemicists, such as F. White and John Sweet in 1617, T. Doughty and an I.C. in 1620, J. Clare and James Sharpe in 1630, a W.S. writing in 1657 against Presbyterians, a J. Mumford in 1658, John Wilson in 1670, an "Ignoramus" in 1678, and Serenus Cressy in 1686, followed Rainold's plotline in citing the apostasy of Joris as the natural outcome of Protestantism. ${ }^{40}$ In 1630 the Jesuit James Sharpe added that Joris saw himself as the nephew of God and as the third David, the latter the first reference to this teaching in English works.

Some Catholic polemicists, clearly without the benefit of the Basel pamphlet, followed different arguments, such as John Price who in 1640 published a defense of Catholicism in which Joris is cited merely as an example as to how Protestants prosecuted heresy as much as Catholics, for did not Protestants

38 Lawrence Anderton, The non-entity of Protestancy. Or a discourse, wherein is demonstrated, that Protestancy is not any reall thing, but in it selfe a platonicall idea; a wast of all positiue fayth; and a meere nothing. Vritten by a Catholike priest of the Society of Iesus (Saint-Omer: English College Press, 1633) [Table 40], 234.

39 Lawrence Anderton, The progenie of Catholicks and Protestants Whereby on the one side is proued the lineal descent of Catholicks, for the Roman faith and religion, from the holie fathers of the primitiue Church ... and on the other, the neuer-being of Protestants or their nouel sect during al the foresayd time, otherwise then in confessed and condemned hereticks. ... (Rouen: Widow of Nicolas Courant, 1633) [Table 41], 8.

40 Table 26, 27, 29, 31, 33, 34, 80, 83, 105, 116, and 125. On Cressy, see Liam Peter Temple, Mysticism in Early Modern England (Woodbridge, 2019), 122-138. 
burn David George in Holland? Apart from the wrong means and location for Joris's demise - he died of natural causes in Basel in 1556 - Price also anachronistically has Protestant rulers in Holland at the time of Joris's death in $1556 .{ }^{41}$ Others simply cited Joris as what can go wrong when the scriptures are translated and left in the hands of untrained layfolk, an argument used by the priest William Warford (156o-16o8) in his 1604 work. ${ }^{42}$ In 1631 Cresacre More took the interesting approach of claiming that Sir Thomas More had prophesied the rise of Joris by citing from his correspondence: "For Germanie now daily bringeth forth more monsters, yea prodigious things, then Africk was wont to doe. For what can be more monstrous then the Anabaptists; ... I ... do expect shortly to heare, that there will arise some, who will not sticke to preache, that Christ himselfe is to be denyed," a passage that Creasacre More claims had foretold of "David George the Hollander, who called himself Christ."43

Rainolds's off-hand comment of "Turkish madness" was merely an extreme version of rumours that Joris promoted toleration for both Jews and Muslims. Another example is provided in Doughty's 1620 polemic extrapolated from the Basel story of Joris to explain how other Protestants, such as Castellio, Ochino, and Adam Neucer, "either turned Turkes or Jewes, seeing the Prophecies not fulfilled in Protestantisme." ${ }^{44}$ In 1630 John Clare responded to Protestant apologists who admitted that while Ochino and Neuserus "had reuolted to Turcisme and Iudaisme," this was a rarity; against this, Clare cites the case of Joris, "a chiefe Protestant, and once Professour at Basil" who also became a blasphe-

41 John Price, Anti-mortonus or an apology in defence of the church of rome against the grand imposture of doctor thomas morton, bishop of durham whereto is added in the chapterXXXIII an answere to his late sermon printed, and preached before his maiesty in the cathedrall church of the same citty (Saint-Omer: English College Press, 1640) [Table 44], 190.

42 William Warford, A briefe instruction By way of dialogue, concerninge the principall poyntes of Christian religio $[n]$, gathered out of the holy scriptures, lathers, and councels (Saint-Omer: English College Press, 1604) [Table 20], 123.

43 Cresacre More, The life and death of Sir Thomas Moore Lord high Chancellour of England. Written by M.T.M. and dedicated to the Queens most gracious Maiestie (Douai: B. Bellière, 1631) [Table 37], 97.

44 Thomas Doughty, An humble appeale to the Kings most excellent Maiestie Wherein is proued, that our Lord and Sauiour Iesus Christ, was authour of the Catholike Roman faith, which Protestants call Papistrie. Written by Iohn Hunt, a Roman Catholike, in defence of his religion against the calumniations and persecutions of Protestant ministers (Lancashire: [Birchley Hall Press?], 1620) [Table 31], 26. 
mous Apostata. After quoting the Basel pamphlet, Clare concludes, "thus that impious Iew." ${ }^{45}$ In 1642 another example appeared as a translation of a treatise by the prominent French Cardinal Jacques Davy du Perron (1556-1618), Luthers Alcoran, attacking French Protestants by associating them with heresy and Islam. Du Perron argues that the most notorious heretics of the sixteenth century were merely the natural result of Protestantism which leads to extreme individualism and atheism. One of his examples was Joris, who, he reports, "being a man of God, vsed the publike Ministery at Basill. Now I say, this Dauid George became a most blasphemous Turke, or Iew, as the Deuine themselues of Basill haue published, and recorded." ${ }^{\text {46 }}$

Is there any truth to this allegation? No. Joris remained a Christian, albeit a deeply idiosyncratic one, until his death in 1556 . Yet, his theological position that none of the externals of religion were of any consequence when it came to salvation often led to charges of atheism. Joris's reputation of tolerating Jews and Muslims was due to his pointing to the Turks as an example of how a state could prosper while allowing other sects and religions, including Judaism and Christianity, to survive. ${ }^{47}$ For Joris, tolerance of religious diversity did not necessarily weaken allegiance to the state, as many of his contemporaries argued, and this example of the Turks would be used by later proponents of religious diversity in the Netherlands. ${ }^{48}$ Orthodox writers decried this posture as heresy, as when in 1545 Strasbourg's Reformed preachers warned their magistrates that Joris and his followers had recently arrived in the region and were openly maligning "Strasbourg's church and religion, some denied the existence of the devil, and others argued that one should tolerate all citizens whether Jew, Turk, or Catholic."49 Many continental polemicists identified Islam as originally a

45 John Clare, The Conuerted Iew or Certaine dialogues betweene Micheas a learned Iew and others, touching diuers points of religion, controuerted betweene the Catholicks and Protestants (n.p., English secret press, 1630) [Table 31], 101-102. He cites the Latin edition of the Basel pamphlet.

46 Jacques Davy du Perron, Luthers alcoran being a treatise first written in french by the learned cardinall peron, of famous memory, against the hugenots of france, and translated into english by N.N.P.: ... (n.p., n.p., 1642) [Table 45], 105. On turning Turk, see D. Vitkus, Turning Turk: English Theater and the Multicultural Mediterranean, 1570-1630 (Basingstoke, 2003); and M. Dimmock, New Turkes: Dramatizing Islam and the Ottomans in Early Modern England (Aldershot, 2005).

47 S. Zijlstra, "De brief van David Joris aan het Hof van Holland, 1539," Doopsgezinde Bijdragen 23 (1997), 133-149, there 147.

48 See Gary K. Waite, Jews and Muslims in Seventeenth-Century Discourse:From Religious Enemies to Allies and Friends (London, 2019).

49 Marc Lienhard, Stephen F. Nelson and Hans Georg Rott, eds, Quellen zur Geschichte der Täufer, vol. 16, Elsass IV, Stadt Straßburg 1543-1552 (Gutersloh, 1988), 119-121. 
Christian heresy, leading them to link Muhammad with various sixteenth century nonconformists, including Joris..$^{50}$ English Catholic writers made the same association, despite their lack of real information about Joris.

The second major source on Joris was that written by the Dutch preacher Martin Micron when he was a pastor in East Frisia. Here Joris's ideas were well known and Joris and his supporters conducted meetings with the Reformed superintendent John a Lasco and published a defense of his ideas written to East Frisia's ruler, Countess Anna of Oldenburg. ${ }^{51}$ It appears, however, that English Protestants had come to appreciate Micron during his time as minister of the Dutch Church at London during the reign of Edward vi. One Protestant writer, John Knewstub, in 1579 cited a work he calls A Confutation of the doctrine of David George, and H.N. the father of the Familie of Love, which he had drawn from Micron's Latin "book concerning holy assemblies," which Knewstub says was translated into English and published by Nicholas Carinaeus, although I have not found a copy. Knewstub cites extensively from it, and it was also cited in Rainolds in 1583. The major point of criticism levelled at Joris from this work was his spiritual perfectionism, which became a major element of the Familists and which Protestant polemicists asserted led directly to Libertinism, to the belief that to the pure, everything is pure. As Knewstub commented, it "is not fayth but a certaine faithlesse and arrogant falling awaye from GOD, and a meere deceipt of the Deuil, to faine that Idolatrie, superstition and outwarde vices are free and pure vnto them, which vnder the pretence of a certaine fayth and inwarde puritie, boast that they knowe no sinne in the heart." Joris, Knewstub also claimed, rejected Jesus Christ, instead he "foolishly fained vnto him selfe a certaine immortalitie in this earth, which he hoped to purchase with the sword for those that were his but in vaine they beeing already dead \& buried," and which his "euyll Chickens", hatched out of Joris's egg, deceive the world as alleged followers of love and peace (i.e., the Familists). ${ }^{52}$

50 Christoffel van Sichem, Grouwelen der voornaemster Hooft-Ketteren ... (Leiden: Jan Claesz van Dorp, 1623).

$51 \quad$ See "The Apology to Countess Anna of Oldenburg, 1540-1543," in The Anabaptist Writings of David Joris, 1535-1543, ed., trans. Gary K. Waite, 2nd ed. (Walden, NY, 2019), 269-286.

$5^{2}$ John Knewstub, A confutation of monstrous and horrible heresies, taught by H.N. and embraced of a number, who call themselues the Familie of Loue (London: for Richard Sergier, 1579) [Table 10], 87-88. 
Micron's work was not, however, nearly as popular as the Basel pamphlet, nor the third principle source, the book by the Reformed preacher Heinrich Bullinger against the Anabaptists. Originally produced in Latin in 156o as Adversus Anabaptistas Libri vi (Against the Anabaptists, Six Books), this work became a standard reference for Protestant writers critiquing the rise of sects. ${ }^{53}$ Bullinger, however, provides little real information about Joris. Even so, he was a major source for particular themes about the Dutch prophet that would appear in English polemics. First, that Joris's teachings were nothing other than a Libertine's cover for a "diabolical impurity" (Tüfelische vnreinigkeyt) for teaching that marriage is free, and that no man is bound sexually to his wife. ${ }^{54}$ Some writers interpreted this to mean that Joris supported polygamy. Second, that the Münsterite Anabaptists believed there were two true prophets, Jan van Leiden and David Joris, who would become the kings of the New Jerusalem. ${ }^{55}$ Third, that Joris, the "greatest blasphemer," not only arose out of the Münsterite Anabaptist movement, thereby possessing a full share in that abomination, but, inspired by the devil, he taught that his ideas superseded scripture, since he was the new Christ, born of the spirit, not flesh. It would therefore be Joris, not Christ, who would conduct the Last Judgement. ${ }^{56}$ Fie this devil, Bullinger expostulates, for who has seen anything comparable since Simon Magus called himself a god, or Machomet founded the Saracen and Turkish faith?

Like so many other writers, Bullinger acknowledges his reliance on the Basel pamphlet, which he notes "appeared in press this year." He is so affronted by Joris's blasphemous claims that he keeps calling him a devil. Yet, importantly, nowhere does he refer to Joris's demonology. So, like the Basel pamphlet, Bullinger does not bring to the attention of English polemicists the spectre of Joris's proto-atheism. While likely utilized by a large number of Reformed writers, Bullinger is cited explicitly in Francis Cheynell's 1643 The Rise, growth, and danger of Socinianisme, D. Featley's Katabaptistoi katabtistoi The Dippers dipt

53 Heinrich Bullinger, Adversus Anabaptistas Libri vI (Zürich: Christoph Froschauer, 156o). A German edition appeared off the same press also in 156o, with a second edition the following year: Der Widertoufferen Vrsprung, fürgang, secten, wäsen, fürnemme vnd gemeine jrer leer artickel, ouch jre gründ und warumb sy sich absünderind, vnnd ein eigne kirchen anrichtind, mit widerlegung vnd antwort vff alle und yede jre gründ und artickel, ... vI Bücher ... (Zürich: Christoph Froschauer, 156o).

54 Bullinger, Widertoufferen Vrsprung (see above, n. 53), fol. $37^{\mathrm{r}}$.

55 Ibid., fols. $51^{\mathrm{v}}-52^{\mathrm{r}}, 53^{\mathrm{r}}$. For the truth of such assertions, see De Bakker and Waite, "Rethinking the Murky World" (see above, n. 5).

$5^{6} \quad$ Bullinger, Widertoufferen Vrsprung (see above, n. 53 ), fols. $6 \mathrm{o}^{\mathrm{v}}-6 \mathrm{1}^{\mathrm{r}}$. 
of 1645, Pagitt's Heresiography of 1645, and Thomas Underhill's 166o Hell broke loose: or an history of the Quakers. All of these follow Bullinger in condemning sectarianism, spiritualism's dangers, and the denial of the divinity of Jesus.

A fourth source widely available on the continent was the illustrated history of the most notorious heretics produced by the engraver Christoffel van Sichem. This first appeared in German, Latin, and Dutch editions starting from c. $1607 .{ }^{57}$ This work was so popular largely because van Sichem included engraved images of the various heretics, most of whom were Reformation radicals, especially Anabaptists, although he begins with the fourth-century anti-trinitarian Arius and follows that with the founder of Islam, the Prophet Muhammad. Yet, once again, there were no references to this work by English polemicists until it was produced in English translation and included in the 1655 second edition of Pansebeia, or, A view of all Religions in the World, by the Anglican polemicist Alexander Ross. He seems to have come across van Sichem's work only after the first edition of Pansebeia had appeared in $16533^{58}$ This is seen also in a $165^{2}$ world history wherein Ross briefly mentions Joris merely as part of a quick overview of the German Reformation: "The Palatinate becomes Protestant. Herman Archbishop of Colen strives to reform Religion, but is crossed by the Clergy and deprived. David George stiles himselfe Christ: he flieth from Delf to Basil. The Councel of Trent begins." Similarly, shortly after this reference, Ross continues, "Protestants persecuted in England; Latimer, Ridley, and Cranmer burnt. The Agreement at Passau confirmed. The body of David George taken out of his grave, and burnt, 3 years after his burial ..."59 While Ross had yet to discover the full story of Joris's heresy, he clearly found him intriguing enough to insert him into this brief history; his curiosity was whetted.

In the first edition of Pansebeia, Ross adds more about Joris, noting that he was a glazier of Ghent who "taught that he was God Almighties Nephew, born

\footnotetext{
57 Van Sichem, Grouwelen der voornaemster Hooft-Ketteren (see above, n. 50).

58 Alexander Ross. Pansebeia, or, A view of all Religions in the World, from the Creation, to these times. Together with a Discovery of all Known Heresies in all Ages and Places (London: for John Saywell, 1653) [Table 74].

59 Alexander Ross, The history of the world the second part in six books, being a continuation of famous history of sir walter raleigh, knight ... (London: for John Saywell, 1652) [Table 73], no pagination, image 380, https://login.proxy.hil.unb.ca/login?url=https://search.proquest .com/docview/2240866702? accountid=14611.
} 
of the Spirit, not of the flesh, the true messiah, and third David that was to reign on Earth; that Heaven was void of inhabitants, and that therefore he was sent to adopt Sons for that heavenly Kingdom." Ross also notes that Joris "denied Spirits, the Resurrection, and the last judgement, and life eternal," while he promoted sexual promiscuity since the soul could not be polluted by sin and further taught that while the infidels would be saved, all bodies, including those of the apostles, would burn in hellfire. And, Joris allegedly criticized the martyrs for "shedding their blood for Christ," something that was unnecessary, since he allowed Nicodemism. ${ }^{60}$ Apart from the Familists, Ross's major target, however, was Islam, and by comparing them to the Anabaptists, he believed he could temper the growing interest in Islam among English readers. ${ }^{61} \mathrm{He}$ also produced a deeply polemical translation of the Qur'an in $1657 .^{62}$

It was only in the 1655 and later versions of Pansebeia that Ross included the full text of Van Sichem's work, thus adding considerably to his critical treatment of the Dutch heretic and of course to the information available to other writers. ${ }^{63}$ This work sought to explain why Joris could attract so many followers and wealth, although most of the material in Van Sichem came also from the Basel pamphlet, and possibly too from Bullinger. Since this work also included reference to Joris's son-in-law, Nicholas Blesdijk, who fell away from Joris shortly before his death and wrote a very detailed critique of his father-in-law, it may have sparked interest in finding Blesdijk's book.

\section{2: Blesdijk's Historia vitae and Joris's Demonology}

English writers thus had very little accurate information about Joris until almost the mid seventeenth century. The first work with new information appeared only in 1646 when a booklet by the Leiden professor Friedrich Span-

6o Ross, Pansebeia (see above, n. 58), 231. Actually, Joris was deeply moved by the deaths of his followers and of the Anabaptists, and frequently wrote condemning persecution.

61 Ibid., 7o.

62 See Gary K. Waite, "Menno and Muhammad: Anabaptists and Mennonites Reconsider Islam, 1525-165o," The Sixteenth Century Journal 41 (2010), 995-1016.

63 Alexander Ross, Pansebeia, or, A view of all religions in the world with the severall churchgovernments from the creation, to these times: also, a discovery of all known heresies in all ages and places ... (London: for John Saywell, 1658) [Table 79, 84]. The Davies translation of van Sichem begins on p. 365: Jo. Davies, Apocalypsis: or, the Revelation Of certain notorious Advancers of Heresie: Wherein their Visions and private Revelations by Dreams, are discovered to be most incredible blasphemies, and enthusiastical dotages: Together with an account of their Lives, Actions, and Ends (London: for John Saywell, 1658) [Table 84]. 
heim on the dangers of Anabaptist heresy was translated. In this work, Spanheim included the detailed information provided by Blesdijk—our fifth major source. Until he abandoned his father-in-law, Blesdijk was Joris's most important lieutenant; after his departure, he was able to land a position as a Reformed minister. ${ }^{64}$ Before his turn away from Joris, Blesdijk wrote works defending Joris's theology, while his later critical works were not, it seems, published during his lifetime. It was therefore not until 1642 that one of these manuscripts was published in its original Latin as Historia vitae, doctrinae, ac rerum gestarum Davidis Georgii haeresiarchae (History of the life, doctrine and achievements of the archheretic David Joris) edited by Jacob Revius and printed in Deventer. ${ }^{65}$ This work makes explicit Joris's real teaching, as well as his unusual sexual ethic that Dutch writers had known about for decades through Joris's own publications and his many opponents. Spanheim's work is translated as Englands warning by Germanies woe: or, An historicall narration, of the originall, progresse, tenets, names, and severall sects of the Anabaptists, in Germany, and the Low Countries. ${ }^{66}$ Along with Blesdijk, Spanheim also cites works by Joannes Wygandus, Joannes Sleydan, and Lambertus Hortensius, whose 1548 Latin account of the Anabaptist tumults was a major source on the continent, and likely informed Bullinger. ${ }^{67}$ But the most important work on Joris by far was Blesdijk's. What does his treatise add to the English debate on Joris?

A great deal. Along with his detailed descriptions of Joris's sexual teaching, Blesdijk contributed a very clear depiction of Joris's demonology, as well as noting that his teaching about the trinity was confusing. It appears from the works examined here that English polemicists suddenly became concerned about Joris's unusual interpretation of supernatural beings only with the publication of Spanheim's account in 1646. This is evident in a 1647 anonymous work, The counter buffe, written against a Mr. Edwards. In this, the author not only refers to Blesdijk's treatise, but cites extensively from it, stating, for example, that "this also is an error revived, held by David George, who lived a hundred

64 Zijlstra, Nicholas Meyndertsz van Blesdijk (see above, n. 2).

65 Blesdijk, Historia vitae (see above, n. 4).

66 Friedrich Spanheim, Englands vvarning by Germanies vvoe: or, An historicall narration, of the originall, progresse, tenets, names, and severall sects of the Anabaptists, in Germany, and the Low Countries (London: n.p., 1646) [Table 55].

67 Lambertus Hortensius, Tumultuum anabaptistarum liber unus (Basel: Johann Oporinus, 1548), and Het Boeck ... van den Oproeren der Weder-dooperen (Enkhuizen:Jacob Lenaertsz Meyn, 1614). The Histoire des Anabaptistes, published anonymously at Paris in 1695, is essentially a translation of Hortensius. See Christian Neff and Harold S. Bender, "Hortensius, Lambertus (1500-1574)," Global Anabaptist Mennonite Encyclopedia Online. 1956. Web. 30 Oct 2018. 
yeares ago; in David Georges life written in Latin by his Son in Law Nicholus Blesdikins page 161, 162," thus providing the first evidence of Blesdijk's use by an English author. He begins with Blesdijk's account of Joris's interpretation of the Fall of Adam and Eve: "tis related that by the Serpent entising our first parents, he meant concupisence, and pleades for an Allegoricall interpretation of the Serpent, because the Historicall narration of the Serpent as it is layd down by Moses (sayth David George) drawes divers absurdities with it."68 While the anonymous author admits that there are allegories and metaphors in scripture, this does not allow individuals such as Joris and Mr. Edwards to apply an allegorical reading to any and all passages of scripture when the plain or literal interpretation is to be preferred. Such, the writer avers, was the case with Genesis, with its clearly historical account of creation and the fall of humankind. In the orthodox reading, the serpent was none other than Satan in disguise.

\section{Scottish Presbyterians, Joris, and the Devil}

In another 1647 publication, Blesdijk's Life and Doctrine of David Joris receives a more detailed treatment. This was in a polemical attack on the new religious groups of the 1640 os by the prominent Scottish Presbyterian minister Robert Baillie (1602-1662), who became a professor at the University of Glasgow in $1642 .{ }^{69} \mathrm{In}$ this work Baillie provides considerable new detail about Joris's career and teachings that accords with Blesdijk's largely accurate account. ${ }^{70}$ For a defender of Presbyterianism, Baillie was fighting a multi-sided battle against the episcopacy of England, the restoration of Catholicism, and the growing variety of new religious groups, some of which were a double threat since

68 The counter buffe or, Certaine observations upon Mr. Edwards his animadversions, touching a pamphlet intituled Little Non-such whereby is discernd how passion or spleene may transport some that would be thought great clerks which according to the proverb, doth not alwayes prove the wisest men. ... (London: for H.T., 1647) [Table 57], 3.

69 https://en.wikipedia.org/wiki/Robert_Baillie. The writer of this entry however claims that "Baillie was a man of learning and ability; his views were wise and temperate rather than extreme, and he played but a secondary part in the stirring events of the time," a perspective that might require revision given the venom he expresses against Anabaptists in this publication.

70 Robert Baillie, Anabaptism, the true fountaine of Independency, Brownisme, Antinomy, Familisme, and the most of the other errours, which for the time doe trouble the Church of England, unsealed. Also the questions of paedobaptisme and dipping handled from Scripture. ... (London: for Samuel Gellibrand, 1647) [Table 58]. 
their spiritualistic ethos and allegorizing of scripture allowed their noxious opinions to penetrate into orthodox communities. Cromwell's government had renounced episcopal and Presbyterian forms of church government both, leading to a period of unconstrained religious diversity, something that Baillie denounced in no uncertain terms, calling this lack of confessional oversight "much worse then a Turkish slavery." He thus decries that a "full liberty must be granted to every Seducer, who will in the most publick places, \& within the doors of our houses also, perswade our loving consorts, our dear children ... to deny Christ, to embrace Mahomets Alcoran, the Jewish Talmud, the fables of the Pagan Poets, in place of the Old and New Testament, for the everlasting destruction of their souls." ${ }^{\text {11 }}$ Britain was no longer the bulwark of Protestantism as popery was now coming in through the back door along with the "Swarm of heresies and sects darkens the sun of truth," overwhelming both state and church. ${ }^{72}$ The Dutch were so preoccupied with reaching out to Catholic France that they too were abandoning their role as defenders of the faith.

It was in this context, then, that Baillie turns to the history of the Reformation in the Netherlands, and to the case of Anabaptism and Joris in particular. Baillie is well informed. He notes how Joris, a citizen of Delft, first achieved fame as "a zealous oppugner of Popery," having been arrested and tortured for his zealous preaching against an "idolatrous procession" (this had happened in 1528). Not content as a Protestant, Joris then joined the Anabaptists, becoming then the "the greatest and worst Heretick" who "ever trod upon the earth." Baillie comments upon Joris's participation in the Bocholt meeting of the Anabaptist remnants, including the Batenburger militants, in 1536, and how the agreement did not last, and most of the Anabaptists were executed, apart from a handful of Batenburgers, which he claims had survived in Moravia (there is of course no evidence of this). He even correctly notes how the Strasbourg Reformer Martin Bucer managed to convert the local followers of Hoffman to the Reformed position; all of these details are from Blesdijk. ${ }^{73}$

It is from Joris's son-in-law that Baillie describes how Joris's movement flourished, for Joris was "a man very pragmatick, of a vehement and perswasive eloquence in the acts of devotion," if excessive in fasting and "wonderfully confident of the absolute truth of his tenets." So confident was he that he wrote to the Holy Roman Emperor and to various princes across the realm. Yet, and this is where Ballie gets to the point of his very extensive treatment of Joris,

\footnotetext{
71 Ibid., fol. ${ }^{*} 3^{\mathrm{v}}$.

72 Ibid., fol. $\mathrm{A}^{\mathrm{v}}$.

73 Ibid., 13-14.
} 
his tenets are so horribly absurd that Mahomet in his worst abominations was far below him, for he taught that in the Godhead was no Trinity of Persons, but only three ways of manifestation, one in Moses, another in Jesus, a third in himself; that his person was as far above the person of Jesus, as Jesus was above Moses; That the writs of the Prophets and Apostles, that the Doctrine of the Law and Gospel was all to be laid aside as childish and imperfect rudiments, to be dispelled as the twilight, by the beams of his far more perfect Doctrine. One of the greatest perfections and singularities I mark in his Doctrine is that which he much insists upon, the mortification of the flesh; to this he leads by a singular method, he looses the bands of Matrimony, and all other naturall and civill relations as things old and antiquate, which did oblige only during the time of Moses and of Jesus, but not under the clear light which his Ministry had brought to the world. ${ }^{74}$

While there is some polemical distortion here, Baillie's summary of Joris's theology is not far wrong; Joris did not deny the trinity, as so many of his critics claimed, but he described it in anthropomorphic terms, since he believed that humans were triune, and created in God's image. For a time he also believed himself to be the third David, but never claimed to be a member of the trinity. In his later writings he asserted that the doctrine of the trinity was not one worth fighting over in any event. ${ }^{75}$ Baillie also notes that, "notwithstanding of the unutterable absurdity of his way," Joris "was confident that the whole world would submit to him, and in a short time would put into his hands without any violence all their power and wealth," referring then to the capture and trial of Joris's followers in Winter 1538/39 in Delft where it seems they had gathered to witness Joris's coronation as the new messianic king. ${ }^{76}$ After this moment, Baillie continues, Joris turned away from the physical fulfillment of prophecy to dissimulation, thus ending the persecution (it, of course, did not). When Joris moved to Basel, the Dutch Anabaptists fell under the leadership of Menno Simons, who rejected the prophecies of the Melchiorites, the violence of the Münsterites, and "most of the blasphemies of David

\footnotetext{
74 Ibid., 14-15.

75 Gary K. Waite, “'Turning Turke the Anabaptist Way': Muslims, Jews, Christian Spiritualists, and Polemical Discourse in the Dutch Republic, c. 1570 to c. 1630," Global Reformations: Transforming Early Modern Religions, Societies, and Cultures, ed. Nicholas Terpstra (London, 2019), 73-94, there 76 .

76 Baillie, Anabaptism (see above, n. 70), 15. De Bakker and Waite, "Rethinking the Murky World" (see above, n. 5), 51, 66-69.
} 
George." Despite this rather positive treatment of Menno, Baillie still criticizes him for "alluring many thousands to his way" of sectarian independency. ${ }^{77}$ Baillie has similarly followed the affairs of the Dutch Mennonites, citing their many schisms as proof that the "wickednesse of that [sectarian] spirit which reigned in Menno" still "rages in his followers, notwithstanding of all their profession of great piety," and remains a great threat to Britain. So too is the depreciation of the divinity of Jesus inherent in their incarnation doctrine (that Jesus received none of his humanity from Mary but brought his "heavenly flesh" from heaven). According to Baillie, the Schwenckfeldians, Servetus, and Sozzini had learned their denial of the trinity from these Anabaptists. Baillie is so well informed that he cites from a Mennonite confession of faith from 1624 and notes the prominent role played by Anabaptist women prophets. ${ }^{78}$ Baillie's is the first detailed exposition of Joris's teaching, not to mention of Dutch Anabaptism, by an English writer that comes anywhere close to the known facts.

Baillie expresses considerable bafflement over Joris's demonology; it is clearly something he had not previously come across. He attributes it to all Anabaptists: "These might have seemed the very quintessence of all imaginable absurdities," he fumes about the alleged sexual improprieties of the heretics, yet there are even worse, for his sources "tell us therefore yet of rarer novelties, of new more excellent lights which they have brought out of heaven" since they had abandoned the scriptures. This "new perfect Doctrine" was "that there is not any created spirit; that Angels and Devils are not substances, but meer qualities; that the spirits of men are but terrestriall vapour, like the life of beasts perishing with the body."79 In other words, Baillie believed that the denial of the existence of angels and demons external to humans led automatically to a materialistic conception of the world, devoid of supernatural beings or involvement. ${ }^{80}$ This, he asserts, was seen in the English Familists, who "do cleave fast to the most of David George his abominations," for they "deny that any mans soul is a living spirit, affirming it to be onely a bodily vapour like the life of beasts, which at death does perish." They allegorize scripture to signify matters in this life, not the next, thus utterly rejecting belief in the torments of hell for the wicked and making God "personally to subsist in every

77 Baillie, Anabaptism (see above, n. 70), 16.

78 Ibid., $17,31$.

79 Ibid., 34 .

8o Baillie continues for several pages to detail the other horrific teachings of Joris and his Dutch fellows. 
creature." ${ }^{11}$ Baillie even has Joris responsible for the rise in incestuous polygamy of his own day. ${ }^{82}$

When Baillie wrote his condemnation of Joris's denial of real spirit beings, the Scots were still pursuing demonic witchcraft on a major scale. In 1647 the English had just experienced the witch panics of Essex (1644-1647); these would lead Cromwell's parliament to suppress such major trials thereafter. Cromwell also replaced Scotland's judges with his own, and they too suppressed witchcraft trials there in the early 165 os. When, however, Cromwell bowed to public pressure to restore the Scottish judges in 1656, they pursued witchcraft prosecution thereafter. ${ }^{83}$ Although Baillie does not reference it here, for most Scottish Protestants demonic witchcraft was real and eradicating its apostasy essential for crafting a godly realm free of blasphemy. ${ }^{84}$ Certainly Baillie feared that doubting the existence of demons would lead naturally to pantheism and materialism. He was not altogether wrong.

Once they became aware of it, other English and Scottish polemicists needed to assault Joris's demonology. ${ }^{85}$ The year after Baillie's tome, another Presbyterian professor, Samuel Rutherford of St Andrew's University, published his Survey of the Spirituall Antichrist attacking Familism and Antinomianism in terms similar to Baillie. He too believed that granting toleration for all was to admit atheism into the realm, while the godly magistrate must suppress the practitioners of "spirituall whoredome" just as he rightfully punishes adulterers, murderers, and the like. ${ }^{86}$ That said, Rutherford avers that he does not wish to force "our opinions on consciences of any," nor do the Scots seek to force "our church government on our brethren in England." ${ }^{87}$ The greatest threat to the purity of the land are the Libertines, who "say with Sadduces, that Angels good or ill, are nothing but imaginations, thoughts, and motions of the minde of man .... They say, man was made of a body and opinion in place of a soule;

\footnotetext{
81 Ibid., 100.

82 Ibid. Baillie (ibid., 102) cites from two recent publications, which he entitles, The discovery of Familisme and The description and confutation of Familisme.

83 Good overviews are provided in Brian P. Levack, ed., The Oxford Handbook of Witchcraft in Early Modern Europe and Colonial America (Oxford, 2013).

84 See Ian Bostridge, Witchcraft and Its Transformations, c. 1650-c. $175^{\circ}$ (Oxford, 1997); and more generally, Julian Goodare, The European Witch-Hunt (Abingdon, 2016).

85 Samuel Rutherford, A survey of the spirituall antichrist opening the secrets of familisme and antinomianisme in the antichristian doctrine of John Saltmarsh and Will. Del, the present preachers of the army now in England ... (London: for Andrew Crooke, 1648) [Table 6o], 4, 13-15.

86 Ibid., fols. $\mathrm{A}_{3}{ }^{\mathrm{v}}-\mathrm{A}_{4}^{\mathrm{r}}$.

87 Ibid., fol. $\mathrm{A}_{4} \mathrm{v}$.
} 
that the other enemy the world is nothing, and sin an naked opinion." 88 Citing from Blesdijk, as well as from other works, he asserts that it was Joris who "transformed the scriptures, in allegories, said Angels were but motions in the minde of man, so do Familists and Antinomians." ${ }^{89}$ Similarly, he and the Familists placed heaven and hell, and the Last Judgement, within each person, denying any external reality for these. ${ }^{90}$ Rutherford finally decries that such Familism is now to be found in New England. ${ }^{91}$

Such concerns over the impact of Joris's demonology culminate in the detailed analysis and dissection by the famed Cambridge Platonist, Henry More in several of his tomes from $1655^{-1660}$, such as Enthusiasmus triumphatus, a work critiquing excessive religious enthusiasm. ${ }^{92}$ A Fellow of the Royal Society, More's arguments are more complex than most, since he is seeking to tread a path between spirituality devoid of reason and reason devoid of spirituality, between excessive Rationalism and spiritualism. As a member of the informal network of philosophers known as the Cambridge Platonists, which included fellow travelers John Smith (1618-1652) and Joseph Glanvill (1636-168o), More's broader goal is to prove the reality of the supernatural world, of God, angels, ghosts, and demons, against the rising tide of materialistic philosophy. ${ }^{93}$ As

\section{Ibid., 4 .}

89 Ibid., 13; in the margin he writes: "See Blesdikus in vita Davids Georgij."

$90 \quad$ Ibid., 14-15. He has Joris's supporters concentrated in "Low Germany and Transilvania."

91 Ibid., 38, 42.

92 Henry More, Enthusiasmus triumphatus, or, A discourse of the nature, causes, kinds, and cure, of enthusiasm ... (London: J. Flesher, 1656) [Table 80]; An explanation of the grand mystery of godliness, or, A true and faithfull representation of the everlasting Gospel of our Lord and Saviour Jesus Christ ... (London: J. Flesher, 166o) [Table 89]; and A Collection Of Several Philosophical Writings of Dr Henry More Fellow of Christ's Colledge in Cambridge. As Namely, Antidote against Atheism. Appendix to the said Antidote. Enthusiasmus Triumphatus. Letters to Des-Cartes, etc. Immortality of the Soul. Conjectura Cabbalistica, 2nd ed. (London: James Flesher, 1662) [Table 95]. Further on More, see: Sarah Hutton ed., Henry More (1614-1617) Tercentenary Studies (Dordrecht, 1990); Jasper Reid, The Metaphysics of Henry More (Dordrecht, 2012); Robert Crocker, Henry More, 1614-1617. A Biography of a Cambridge Platonist (Dordrech, 2013); Lawrence Eliot Klein and Anthony J. LaVopa, Enthusiasm and Enlightenment in Europe, 1650-1850 (San Marino, CA, 1998). On the broader philosophical debates, see Frederick C. Beiser, The Sovereignty of Reason: The Defense of Rationality in the Early English Enlightenment (Princeton, NJ, 1996).

93 See esp. William Cook Miller, "The Enthusiast: What Radical Religion Did to Character," book ms under review with Cornell University Press; I am thankful to William Miller for 
explained especially by Smith, divine revelation or inspiration flows freely from the divine, and this "prophetical influx" is first received in the person's imagination; should it remain there in one who is unprepared, it leads to delusion. Those who are "fit vessels" or true prophets will instead reflect on the "influx" using their mind, and become true prophets illuminated in both their imagination and reason..$^{94}$

In Enthusiasmus triumphatus, More is also responding to the sudden rise of religious groups that emphasized the Spirit within and which inspired women and men to speak for the divine. What gave these individuals such presumptive authority? It was, he begins, "the enormous strength of Imagination the cause of Enthusiasme." ${ }^{\prime 95} \mathrm{He}$ therefore follows Robert Burton's physiological explanation for why so many were falling into the trap of "Enthusiasme." This was, he explained, through the "power" of diet or disease to alter the imagination, especially when the visionary was suffering from Melancholia, the excess of black bile that unbalanced the mind and brought on hallucinations. Heated Melancholy was frequently mistaken for holy zeal and the Spirit of God, More continues, and it disposes people to "Apoplexies and Epilepsies," to unfounded visions and revelations. ${ }^{97}$ In this category he includes the Religious Society of Friends, whose physical manifestations of inspiration their opponents had called "quaking," hence Quakers. More notes the popularity of Paracelsian alchemical medicine, and while he claims that he is "no foe to either Theosophist or Chymist" — he had friends who were so inclined-he asserts that Paracelsus has "given occasion to the wildest philosophick Enthusiasmes that ever was yet on foot," while his philosophy unintentionally provided

sharing this ms with me. See also Euan Cameron, Enchanted Europe: Superstition, Reason, \& Religion, 1250-1750 (Oxford, 2010), 275-282; on this need to find proof of the reality of the spirit world by recourse to the physical relationships between witches and demons, see Walter Stephens, Demon Lovers: Witchcraft, Sex, and the Crisis of Belief (Chicago, IL, 2001), also Robin Briggs, "Dubious messengers: Bodin's daemon, the spirit world and the Sadducees," in Angels in the Early Modern World, ed. Peter Marshall and Alexandra Walsham (Cambridge, 2006), 168-19o.

94 John Smith, Select discourses ... as also a sermon preached by simon patrick ... at the author's funeral; with a brief account of his life and death (London: J. Flesher, 166o), 169-251; I am thankful to William Miller for this reference.

95 More Enthusiasmus triumphatus (see above, n. 92), fol. A3 .

96 The Melancholia diagnosis of religious extremism was developed by Robert Burton in 1621 in The Anatomy of Melancholy. See Angus Gowland, "The Problem of Early Modern Melancholy," Past \& Present 191 (2006), 77-120. See also Temple, Mysticism (see above, n. 40), 77-108.

97 For the full list of the afflicted, such as Paracelsus, see More, Enthusiasmus triumphatus (see above, n. 92), fols. $\mathrm{A} 3^{\mathrm{v}}-\mathrm{A} 8^{\mathrm{v}}$. 
sanctuary "for the Atheist, and the very prop of ancient Paganisme," as it justifies worship of the stars (astrology) and derogates the authority of Christ's miracles. ${ }^{98}$ David George was another of these so disturbed by their humoral imbalances, and More reserves a distinctive diagnosis for him. ${ }^{99}$

Before turning to More's analysis, it is important to note that the Melancholia diagnosis had been used for over a century in a bid to suppress witchcraft prosecution. In 1563Johan Wier (Weyer), chief-physician to the Duke of Cleves/ Jülich/Berg, published his De praestigiis daemonum in which he argued that old women who confessed to witchcraft were instead suffering from Melancholia and should be treated medically, not judicially. ${ }^{100}$ Wier's goal was to suppress the rise of witchcraft prosecution, and while his treatise did not succeed in the short term, as the major witch panics were only just beginning in the Holy Roman Empire, Protestant theologians were increasingly prone to use his arguments to caution rulers and judges against allowing such abuses of justice. ${ }^{101}$ One of the recent discoveries about Wier has to do with his religious identity, which has been identified variously as Lutheran, Reformed, and Catholic. Dutch historian Hans de Waardt, however, has shown that he was a spiritualist, albeit one more successful in hiding this compared to his mystical brother, Matthias. ${ }^{102}$ Wier was also a correspondent of Joris, and while his discussion of the devil in De praestigiis appears on the face of it orthodox, he does restrict the devil's primary impact to disturbing the mind of indi-

98 Ibid., points $45^{-} 5^{\text {o }}$ [fol. A $\left.8^{\mathrm{v}}\right]$.

99 More's use of Joris had been earlier noted by Stuart Clark, 2007 Vanities of the Eye: Vision in Early Modern European Culture (Oxford, 2007), 161; and Catherine Wilson, "Enthusiasm and its Critics: Historical and Modern Perspectives," History of European Ideas 17 (1993): $461-478$, there $462-465$, but without any reference to its significance for the reception of Joris; but see now Miller, "The Enthusiast" (see above, n. 93). Both More and Smith cite Wier; Smith, Select discourses (see above, n. 94), 193; More, Enthusiasmus triumphatus (see above, n. 93), 104 .

100 George Mora, et al., eds, Witches, Devils, and Doctors in the Renaissance:Johann Weyer, De praestigiis daemonum (Binghamton, N.Y., 1991).

101 Wolfgang Behringer, Witchcraft Persecutions in Bavaria: Popular Magic, Religious Zealotry and Reason of State in Early Modern Europe (Cambridge, 2003), 213-224.

102 Hans de Waardt, "Witchcraft, Spiritualism and Medicine: The Religious Convictions of Johan Wier," Sixteenth Century Journal 42 (2011), 369-391, and "Inflating the Prestige of Demons: Johan Wier's Role-playing," forthcoming in Church History and Religious Culture 101 (nos. 2/3 2021); see also Gary K. Waite, "Radical Religion and the medical Profession: The Spiritualist David Joris and the Brothers Weyer (Wier)," in Radikalität und Dissent im 16. Jahrhundert / Radicalism and Dissent in the Sixteenth Century, special edition of the Zeitschrift für historische Forschung, ed. Hans-Jürgen Goertz and James M. Stayer (Berlin, 2002), $167-185$. 
viduals, rather than the body, which is not far from a Joristic interpretation in any event. Despite Wier's orthodox language, his intent, as stated by Stuart Clark, "was to reveal 'the impotence of the demon." "103 He also sought to end the religious violence and persecution of heresy that plagued both his Netherlandic and German homes. If he had to utilize orthodox language to convince his audience, then that form of dissimulation was a well-practiced craft of the spiritualist. As Clark has also noted, Scot's Discoverie of Witchcraft was too radically skeptical a treatise on the devil to gain any traction for over a century. ${ }^{104}$ Even so, Scot relied heavily on Wier; it is quite possible that he knew how to decode Wier's true message about the impotence of Satan.

This helps explain More's interpretation of Joris and why it was so important to counteract his heresy. More wanted to retain belief in the supernatural intervening in the natural world and in the ability of the divine to inspire an individual without falling into the excess of "Enthusiasm." He therefore had to tread carefully; in the "Song of Platonick Faith," the hero of More's dialogue, Mastix, vehemently rejects the "Deified rout of Ranters and Libertines" by magnifying "the dominion of his own minde over the passions of the body."105 One can be enlightened by the divine light without becoming some "bestrid Pythonick or hackneyed Enthusiastick." The lamp of God which enlightens his Reason and "Fancie" both is "that true Chymicall fire that has purged my soul and purified it." So inspired, Mastix can affirm that this true divine intervention surpasses "all the power and knowledge in Nature, that is, all the feats and miraculous performances done by Witches, Magicians, or Devils, they be but toyes and tricks, and are no solid satisfaction of the soul at all, (yea, though we had that power upon lawfull terms) if compared with this." God has indeed become his intimate as his soul united with the divine who speaks not in parables but intelligently, "plainly in his own language." The allegorical speculations of others are therefore no sign of divine intervention. ${ }^{106}$ It is for this reason that More, at this early stage, liked the philosophy of Descartes which he believed accorded neatly with his emphasis on the union of the soul with God, for this occurred in the spiritual, not the natural world. This, in contrast to the enthusiastic excesses of the Familists, is the true "godded with God, and

\footnotetext{
103 Stuart Clark, Thinking with Demons: The Idea of Witchcraft in Early Modern Europe (Oxford, 1997), 202, citing the 1583 edition of De praestigiis daemonum (Basel, Johann Oporinus, 1583), 86.

104 Clark, Thinking with Demons (see above, n. 103), 212.

105 More, Enthusiasmus triumphatus (see above, n. 92), 298, the Song of "Platonick Faith."

106 Ibid., $177-178$.
} 
Christed with Christ," he exclaims, if you like that sort of language. Those others who claim such deification have instead become "sinks of sinne", "black like brutes or devils" whose false spirituality always leads to sexual sin. ${ }^{107}$ Previous prophets of deification, such as Niclaes and Joris, had merely used their teaching of divine union as an excuse to remain in their sins, and thus they remained Libertines for whom there is no longer any sin. They are also atheists who have bartered away "sound reason and the sober faculties of the soul for boisterous words of vanity, and unsettled conceits of Enthusiasts," without reason, scripture, and "conspicuous miracle" to prove their claims. God, he asserts, does not ride the person like a horse, but guides as a friend, conversing in ways that are comprehensible and clear, using the individual's faculties, not neglecting them. ${ }^{108}$

More's argument thus requires him to rebut the claims of other spiritualists as false, as devoid of reason, as excessive enthusiasm. He is often left uncertain as to whether a particular mystic is true or not; this was the case when asked by Anne Conway whether or not the alchemical spiritualist Jacob Boehme was reliable. ${ }^{109}$ His answer in Enthusiasmus triumphatus of 1656 was mixed, for while it was clear that spiritualists like David George were "at the best but Enthusiastick Sadduces," Boehme instead held firm to the fundamentals of the Christian faith, declaring his love for Jesus with his last breath. But, while More admits to the "sanctity of the Man, and look upon him as one that is as much beyond the other two" since he boasted less of being the equal or superior to Christ, as had Joris and Niclaes, he is unwilling to grant his writings divine authority. ${ }^{110}$ Instead, he describes Boehme as one of those whose

Imaginative facultie has the preheminence above the Rationall; and though he was an holy and good man, his naturall complexion notwithstanding was not destroyed, but retained its property still; and therefore his imagination being very busie about divine things, he could not without a miracle fail of becoming an Enthusiast, and of receiving divine truths upon the account of the strength and vigour of his Phansie: Which being so well quallified with holinesse and sanctity, proved not unsuccesfull in sundry apprehensions, but in others it fared with him after the manner of

\footnotetext{
107 Ibid., 180.

108 Ibid., 182-183.

109 Hutton, Anne Conway (see above, n. 92), 63-65, on her dispute with Henry More over his diagnosis of George, Niclaes, and Boehme as mentally disturbed enthusiasts.

110 More, Enthusiasmus triumphatus (see above, n. 92), 294.
} 
men, the sagacity of his imagination failing him, as well as the anxietie of reason does others of like integrity with himself. ${ }^{111}$

Falling into the error of enthusiasm may thus be due to one's natural temperament, rather than to diabolical inspiration.

It is in this context that More expends considerable ink in elucidating the David George phenomenon, explaining his psychology and attacking his spiritualistic approach as the gateway to atheism, responsible for the other forms of spiritualistic enthusiasm sweeping England that he believed were devoid of reason. Since the Platonist More wanted to retain belief in the supernatural world that interacted with the natural-something that when a prophet Joris had himself felt in dramatic ways-Joris's denial of the reality of angels required serious explanation. More thus turned to Galenic medical theory to explain Joris, asserting that he had a "Sanguine Temper" in which are housed "the fiercer Passions," and suffered also from a dose of Melancholia, which also explained his allowance of polygamy, since this psychological disposition meant that Joris was not stable enough to combine true spirituality with reason, as More himself sought to do. ${ }^{112}$ Instead, when out of balance, the Sanguine temper made Joris susceptible to lust, to religious passions ungoverned by reason, to excess in both thought and desires. Whereas Muhammad's doctrine was, in More's mind, "an abuse of certain principles" of the doctrines of Moses and Christ for a political goal, it was "far to be preferred before the vain and idle Enthusiasmes of David George; who yet was so highly conceited of his own light, that he hoped to put Mahomet's nose out of joynt." For, intoxicated by his "own Melancholy and Sanguine," Joris had the temerity to declare himself "the last and chiefest prophet," denying heaven, hell, eternal reward or punishment, demons and angels, and the immortality of the soul. "Though born a Christian, yet he did Mahomitise in this that he also did indulge plurality of wives."113 More thus has Joris as a bogus prophet who refused to entertain the existence of anything beyond this life. His explanation for this contradiction is that there was "a dash of Blood" (Sanguine) mixed in with his Melancholy. Reciting the summary of Joris's teaching from the Basel pamphlet, More adds that Joris proclaimed himself the messiah born of the Spirit, but "which God had reserved in a secret place, his body [i.e., Christ's] being reduced to nothing, and has infused it wholly into the soul of David George."114 And, of course, that he taught "that

\footnotetext{
111 Ibid., 295.

112 This discussion is based on ibid., 31-38.

113 Ibid., 22.

114 Ibid., 32-33.
} 
Angels and Devils are onely good men and evil men, or their Virtues and Vices." No further evidence for More's diagnosis is required, as he believes that the Sanguine temperament disposes men to the excessive love of women, which Joris's denial of spirit beings helped justify, since without fear of eternal judgement, he could indulge his earthly lusts. ${ }^{115}$

How More was able to determine the psychological profile of a person dead for over a century is a question left unanswered, although it must be noted that in an anonymous biography of Joris that was composed during his life, the prophet is said to have been "born of the complexion of love" and inclined to show affection, sometimes excessively so, as a result. ${ }^{116}$ This biography, however, was not, as far as we know, published until Arnold's Impartial Church and Heresy History of $1700 .{ }^{117}$ Blesdijk's History of the Life and Doctrine of David Joris says a great deal about Joris's unusual teachings about sex, marriage, and reproduction, especially how these were not to be suppressed but transformed so as to produce the pure children of God. ${ }^{118}$ Yet Blesdijk's book says little about Joris's nature or psychology.

More also seems blissfully unaware of the contradiction in his denial of Joris's visionary claims while at the same time seeking to prove the existence of God through the confessions of witches who confirmed that they had sex with demons. ${ }^{119}$ More fears the popularity of the mechanical philosophy and the growing skepticism toward the diabolical side of the supernatural, blaming David George for much of it. While More too was a spiritualist, he refused to go to Joris's extreme of internalizing spirit beings, instead using stories of demoniacs to counteract growing materialism and skepticism. Thus, Joris and Niclaes ("the begodded man of Amsterdam") were greater threats to the survival of Christianity, than even Muhammad. While the Prophet "was fain to walk to the mountain, when he saw the mountain would not move to him,"

\footnotetext{
115 Ibid., 36.

116 Waite, The Anabaptist Writings (see above, n. 51), 68.

117 Arnold, Unparteyische Kirchen- und Ketzer-historie (see above, n. 9), 703-737.

118 Blesdijk, Historia Vitae (see above, n. 4), 24-37; see Zijlstra, Blesdijk (see above, n. 3), 165171; Waite, David Joris (see above, n. 2), 104-106, 207-209.

119 Henry More, An antidote against atheisme, or, An appeal to the natural faculties of the minde of man, whether there be not a God (London: Roger Daniel, 1653), esp. 112-115; More's fellow Platonist, Joseph Glanvill, was particularly obsessed with using witch confessions to prove the existence of God in Saducismus triumphatus, or, Full and plain evidence concerning witches and apparitions in two parts ... With a letter of Dr. Henry More on the same subject and an authentick but wonderful story of certain Swedish witches done into English by Anth. Horneck (London: for J. Collins, 1681). See also Brian P. Levack, The Witch-Hunt in Early Modern Europe, 4th ed. (Abingdon, 2016), 242; and Cameron, Enchanted Europe (see above, n. 93), 275-282.
} 
Joris "brought heaven to earth in his vain imagination."120 English writers like More had only recently stumbled upon Joris's ideas in detail, and they became very curious indeed.

This is evident in the collection of correspondence of the German natural philosopher Samuel Hartlib (c. 16oo-1662), since 1628 a resident of England and a central figure in the cross-Channel circle of leading scientists and philosophers. These letters reveal that More's analysis of Joris sparked considerable interest in the Dutch spiritualist, and inspired others to get a copy of Blesdijk's Historia Vitae. ${ }^{121}$ For example, in a January 30, 166o (Ns) missive to one of the Cambridge Platonists, John Worthington (1618-1671) — who in December 1659 had put together his deceased friend John Smith's papers for publication-, ${ }^{122}$ Hartlib commented:

Mr. More's elaborate piece will no doubt be a universal blessing to all the world. I wish it were extant already. I have written long ago for Vita Davidis Georgii, but could never get an answer of it. The title being now fuller directed, I hope I shall have better success. I shall also make my best enquiry after $\mathrm{H}$. $\mathrm{N}$ tho' it will be very difficult to get a plain impartial account, \& a true character of him.... I have seen none of those books which you mention to have been written against or for David George. ${ }^{123}$

Hartlib implies that it was More's manuscript (presumably of the second edition of the Enthusiasmus triumphatus which came out in 166o) that made him curious to find more information on Joris (and Niclaes), and this set off a quest to find a copy of Blesdijk. In June 166o Hartlib reported to Worthington that he had not yet found a copy, ${ }^{124}$ while a year later Hartlib tells Worthington that he had asked the Scottish irenicist and chiliast John Dury (160o-1680), who

\footnotetext{
120 More, Enthusiasmus triumphatus (see above, n. 92), 36.

121 The Hartlib Papers. Ed. M. Greengrass, M. Leslie, and M. Hannon (2013). Published by HRI Online Publications, Sheffield, available at: https://hridigital.shef.ac.uk/hartlib/. I am thankful to Francesco Quatrini for bringing these references to my attention.

122 Smith, Select Discourses (see above, n. 94), xxxi.

123 Letter, Hartlib to John Worthington, Hartlib Papers (see above, n. 121), 30 January 1659, from The Diary and Correspondence of Dr. John Worthington, ed. J. Crossley. vol. I. (Manchester, 1847), 162-177, there 168-169.

124 Letter, Hartlib to John Worthington, 4 June 166o, ibid., 192-199, there 198.
} 
was at that moment in Amsterdam, to provide more information about Joris and Blesdijk. ${ }^{125}$ Dury replied in August with the discouraging news that none of Leiden's bookshops had a copy, and the book dealers affirmed that the Historia Vitae was long out of print, and hence the book could only be found by chance. ${ }^{126}$ This Hartlib then reported to Worthington, noting, moreover, that he had also asked Henry Oldenburg (c.1619-1677), another German scholar resident in England, to search for a copy of the Historia Vitae in other Dutch cities, but again, without luck. ${ }^{127}$ Despite the failure, Worthington expressed appreciation for Hartlib's efforts, on 22 August 1661 commenting, "I thank you for writing about Blesdikius de Vita Davidis Georgii. The reason why it is desired is a publick good; a worthy person being to write against Enthusiasm, who hath seen his Life set out by those of Basil, might make good use of a further discovery of David George." He also informed his correspondent about More's revisions of his "Philosophical Treatises." ${ }^{28}$ A couple weeks later Worthington reported that "If you consult your catalogue of books printed in Holland anno 1642, you may see by whom, and for whom, Vita Davidis Georgii was printed; which may better direct to the procuring of it. It was put to the press ex Musæo Ja. Revii [Jacob Revius], who was no friend to the fancies of David George." Worthington then commented upon Franciscus van Helmont's intriguing theory that a good angel never appeared bearded, and that Adam became bearded only after Cain's murder of his brother. This was, obviously, part of a broader debate over the appearance of angels, and Worthington concludes by citing More's third book against atheism, that angels "have no settled form, but what they please to give themselves upon occasion." 129

Putting these various snippets of conversation together, it is clear that More's attempts to explain Joris arose out of the broader debate over the reality and nature of spirit beings. Joris's denial of any creaturely aspect to angels and demons was thus a major challenge that needed to be counteracted. More was fortunate, it seems, to find a copy of Blesdijk's book on the prophet, and he inspired a hunt for the now rare volume by members of the intriguing circle of

\footnotetext{
125 Letter, Hartlib to John Worthington, 11 June, 1661, ibid., 335-337, there 335.

126 Letter, John Dury to Hartlib, Hartlib Papers (see above, n. 121), 5 August 1661, Ref. 4/4/29AB.

127 Letter, Hartlib to John Worthington, Hartlib Papers (see above, n. 121), 10 August 1661, from Crossley, The Diary, 350-353, there $35^{\circ}-35^{2}$.

128 Letter, John Worthington to Hartlib, Hartlib Papers, 22 August 1661, ibid., 353-356, there 353 and 356 .

129 Letter, John Worthington to Hartlib, Hartlib Papers, 5 September 1661, ibid., vol. II, part 1, 2-13. On the interpretation of hair, see Edith Snook, ed., A Cultural History of Hair in the Renaissance vol. 3 (London, 2019).
} 
philosophers who were, like More, seeking to promote the verity of the supernatural realm against the rising tide of skepticism. These scholars therefore recognized the importance of Blesdijk's account, referred to the Basel pamphlet, and made it very clear that there still remained little detailed information on Joris. Even so, they wanted to know more about him and his controversial ideas, information that was not just based on hearsay or second-hand accounts.

Publications referencing Joris continued apace over the last decades of the seventeenth century, particularly in works critical of the sectarians and Quakers. In 1667, for example, Jeremy Taylor associated the latter with the Libertines who in Germany were called "Spirituales" who taught that scripture was a dead letter. These were led, of course, by Joris, Niclaes, Schwenckfeld, and the German spiritualist Sebastian Franck. ${ }^{130}$ In 1670 an anonymous anti-Quaker broadsheet told them that Joris was the first of their sect. ${ }^{131}$ The Quaker George Whitehead responded to that charge by agreeing that Joris's doctrines were blasphemous for proclaiming himself to be Christ, and licentious for advocating polygamy. ${ }^{132}$ Three years later Henry Hallywell reiterated the accusation that the Quakers were modern Jorists, this time adding that both Joris and Niclaes taught that they had received their doctrine from the angel Gabriel, a rather strange extrapolation given Joris's denial of the reality of angels. ${ }^{133}$ In 1677 Richard Gilpin, in his Demonologia sacra associated the Ranters and Quakers with the ravings of Niclaes and Joris who believed they were godded with God. ${ }^{134}$ Thomas Comber claimed that the Quaker's predecessors included not just Joris and Niclaes, but

130 Jeremy Taylor, The second part of the dissuasive from popery in vindication of the first part (London: for R. Royston, 1667) [Table 99], 73.

131 An answer to a seditious libel, called, A declaration from the people of God called Quakers, $\& c$. Wherein is discovered, that theirmeetings are seditious conventicles, and that they are not clear from dangerous practises against church and realm (London: n.p., 1670) [Table 103].

132 George Whitehead, The popish informer reprehended for his false information against the Quakers meeting in reply to ... An answer to a seditious libel (London: n.p., 1670) [Table 107], $5^{-6 .}$

133 Henry Hallywell, An account of familism as it is revived and propagated by the Quakers shewing the dangerousness of their tenets, and their inconsistency with the principles of common reason and the declarations of Holy Scripture (London: for Walter Kettilby, 1673) [Table 110], 16.

134 Richard Gilpin, Demonologia sacra, or, A treatise of Satan's temptations in three parts (London: for Richard Randal, 1677) [Table 116], 214. 
also "Mahomet."135 For his part, John Brown called Quakerism the path-way to paganism, referring to Libertines, Familists, and Jorists in both Old and New England who were leading others to non-belief. ${ }^{136}$ Sir Roger L' Estrange joined the chorus in 1680 when he condemned the Quakers and Ranters by association with the deceptions and pretended revelations of Joris and Niclaes. ${ }^{137}$

Catholic polemicists continued the old story of Joris's apostasy as a logical outcome of Protestant theology, but broadening its impact; John Wilson, for example, noted that Joris had been a "pious public Professor of Protestancy" until the logic of Protestantism led him to horrid apostasy; when followed strictly, this faith also leads, he added, to Judaism, Atheism, Arianism, Mahometism, and Socinianism. ${ }^{138}$ Others revealed the great depths of misinformation: in 1678 "Ignoramus" converted Joris from a professor of Protestantism into a Professor at Basel, while a J.V.C.D. suggested that all the leaders of the Reformation had been originally Catholic priests, including David George from "Transilvania."139 Protestant polemicists, such as the Puritan Richard Baxter who, like More, was seeking to prove the verity of the supernatural world, used Joris as an example of the dangers of allowing revelations outside of the letter of scripture, and which were culminating with the "Grundletonians," Familists, Ranters, Seekers, and Quakers of his own day. ${ }^{140}$ In 1691 he followed this with a stronger condemnation in his treatise seeking to prove the reality "of the worlds of spirits," in which he saw Satan's hand in the delusions of Joris and his fellows, concluding that "When the Quakers first rose here, their Societies began like Witches, with Quaking, and Vomiting, and Infecting others, with breathing

135 Thomas Comber, Christianity no enthusiasm, or, The several kinds of inspirations and revelations pretended to by the Quakers (London: for Henry Brome, 1678) [Table 118], 155.

136 John Brown, Quakerisme the path-way to paganisme, or, A vieu of the Quakers religion (Edinburgh: for John Cairns, 1678) [Table 117], 51.

137 Sir Roger L'Estrange, The casuist uncas'd, in a dialogue betwixt Richard and Baxter, with a moderator between them ... (London: for H. Brome, 1680) [Table 120], 15-16.

${ }_{13} 8$ John Wilson, $A$ treatise of religion and governmemt $[$ sic] with reflexions vpon the cause and cure of Englands late distempers and present dangers ... (London: n.p., 1670) [Table 108], 224.

139 Ignoramus, A postscript of advice from Geneva to be added to each of Mr. Care's several volumes of Advice from Rome (London: n.p., 1678) [Table 119], 6; J.V.C.D. To Catholiko Stillingfleeton, or, An account given to a Catholick friend, of Dr. Stillingfleets late book against the Roman Church (Bruges: Luke Kerchove, 1672) [Table 109], 75.

140 Richard Baxter, The cure of church-divisions, or, Directions for weak Christians to keep them from being dividers or troublers of the church with some directions to the pastors how to deal with such Christians (London: for Nevil Simmons, 1670) [Table 104], 164-165; and The life of faith in three parts, the first is a sermon on Hebrews 11, 1, formerly preached before His Majesty ... (London: for Nevil Simmons, 1670) [Table 105], 138-139. On Baxter and More, see Cameron, Enchanted Europe (see above, n. 93), 276. 
on them, and tying Ribbons on their Hands. And their Actions as well as their Doctrine shewed their Master," which was of course the devil. ${ }^{141}$ Also lacking subtlety was the titlepage image of Daniel Featley's 1645 The dippers dipt, or, The Anabaptists duck'd and plung'd over head and eares ... which includes William Marshall's The Description of the Several Sorts of Anabaptists with an image of Joris with a demon entering or speaking into his mouth (see Figure 1). ${ }^{142}$ The assumption was, of course, that only someone inspired by the devil would deny his existence.

Yet, there were a couple voices of dissent, the first coming from none other than William Penn, the Quaker founder of Pennsylvania. Responding to Hallywell and other critics of the Friends, Penn counters that Hallywell: "bestows many severe Expressions upon them [i.e., spiritualists like Joris], more, I think, then becomes a Man of any Charity to give. I am not their Advocate; But so much Splene and so little Reason against Dead Men can be neither Christian nor Manly."143 This is a remarkable statement in the light of the dozens of calumniations of Joris and his ilk that had preceded it. That one simple sentence reveals Penn to have had a very different approach to humanity than most of his peers. Then, in 1683, two other works, both written by Dutch authors, appeared in English translation; the first was the mystical book of Matthias Wier (Weyer), brother to Johan, which first appeared in Dutch in 1579, in which Wier, whose mysticism was very close to Joris's, still has to disassociate himself from the prophet by saying "some erroneous spirits (David George and Henry Nicholas) do profess, who think such things are lawful for them, which are not of themselves lawful, but are wicked and unjust before God, and the Elect: by which they demonstrate that they falsly boast themselves of their dying, and death. Let all those, who desire to find out God beware of these kind of men."144

141 Richard Baxter, The certainty of the worlds of spirits and, consequently, of the immortality of souls of the malice and misery of the devils and the damned (London: for T. Parkhurst, 1691) [Table 132], 175 .

142 Daniel Featley, The dippers dipt, or, The anabaptists duck'd and plung'd over head and eares, at a disputation in Southwark: together with a large and full discourse of their 1. Original. 2. Severall sorts. 3. Peculiar errours. 4. High attempts against the state. 5. Capitall punishments, with an application to these times (London: for Nicholas Bourn, 1645) [Table 49].

143 William Penn, Wisdom justified of her children from the ignorance and calumny of H. Hallywell in his book called, An account of familism as it is revived and propagated by the Quakers (London: n.p., 1673) [Table 111], 31.

144 Matthias Weyer, The narrow path of divine truth described from living practice and experience of its three great steps, viz Purgation, illumination \& union according to the testimony of the holy scriptures ... (London: for Ben Clark, 1683) [Table 124], 229. On Wier and Joris, see de Waardt, "Inflating the Prestige of Demons" (see above, n. 102). 


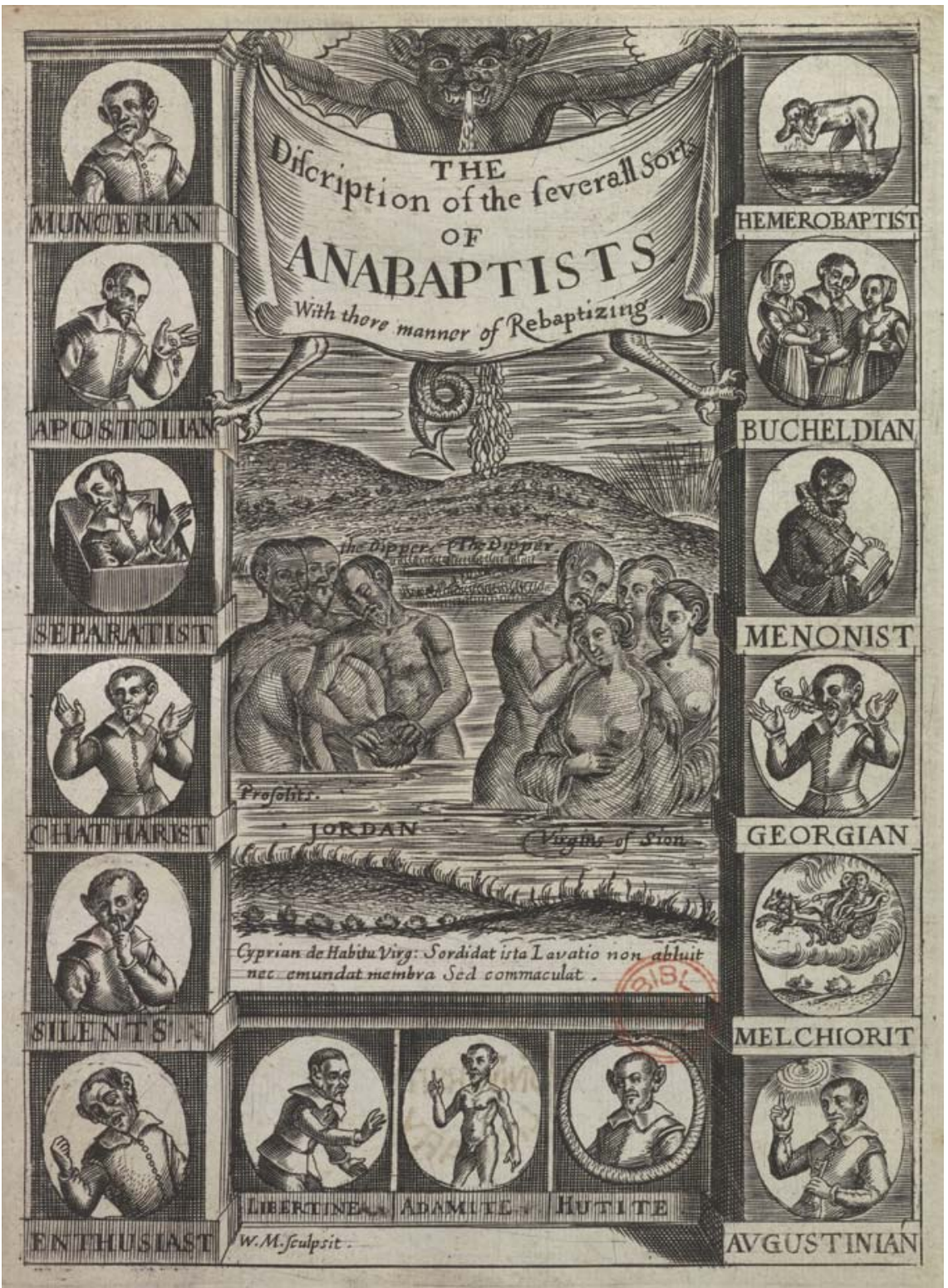

FIGURE 1 Daniel Featley, The dippers dipt, or, The anabaptists duck'd and plung'd over head and eares, at a disputation in Southwark: together with a large and full discourse of their 1. Original. 2. Severall sorts. 3. Peculiar errours. 4. High attempts against the state. 5. Capitall punishments, with an application to these times (London: for Nicholas Bourn, 1645), titlepage F.3.117. REPRODUCED BY KIND PERMISSION OF THE SYNDICS OF CAMBRIDGE UNIVERSITY LIBRARY 
So, while defending spiritualistic mysticism, he still did not want to be tarred by the Joris brush.

The other publication was altogether different. This was a work by Quirinus Kuhlmann (1651-1689), an intriguing German poet who in his youth experienced visions of Jesus Christ after reading Jacob Boehme's Mysterium Magnum and who, like Joris, became convinced by associates that he was the herald of the messiah's return. Even so, he turned to the study of law, first at Jena, then at Leiden in 1673, where his messianic inclinations were revived thanks to the strength of chiliasm in the Dutch Republic. He now proclaimed himself the son of the Son of God and embarked on a missionary enterprise, which took him to Lübeck, London, the Ottoman Empire, and finally Russia, where he was executed for his theological views. ${ }^{145}$ It is no wonder then that he cites positively from Joris's Wonder Book, as well as from Boehme and several other mystics. He vigorously defends Joris from his many detractors, complaining,

who was more trod under foot by wicked Judges than Jacob Behmen, and before him David George, that Man of God, whose Wonder-Book was Printed in the year 1551 ? The wonderful Life of which Men, with others like them, shall be set down in the Book of the three Heroes, in the Third Part of the Scripture, which will be a kind of new Book of Judges; to the which also belong the Lives of John Engelbrecht, and Paul Felgenhauer, and many others yet alive, as well as their Writings, which being first sifted from any remaining Chaff, shall constitute the Doctrine and Church-Books of the approaching Time ... nor ever more assured of the gracious presence of God, than when all men Judged and Condemned me; since it is most true according to the words of David George, that to be Condemned and Judged here on Earth, is to be Justified and Blessed in Heaven. ${ }^{146}$

It is perhaps not surprising then that Kuhlmann looked to Joris for support, since the two shared the same kind of negative response to their prophetic

145 Wilhelm Schmidt-Biggemann, "Salvation through Philology: The Poetical Messianism of Quirinus Kuhlmann (1651-1689)," in Toward the Millennium: Messianic Expectations from the Bible to Waco, ed. Peter Schäfer and Mark R. Cohen (Leiden, 1998), 259-298, there 262.

146 A. Z! Quirin Kuhlman a Christian Jesuelit his Quinary of slingstones against the Goliah of all kindreds, people, and languages: to be placed before his writings, as an invincible loveapology for, and defence of them. For an eternal memory set down the same day which two years before, he departed from the Rose-lilly Bromley by Bow, near London, towards Constantinople, otherwise called, Eastern-Rome, in the lilly city Paris, the 3. day of March (London: for the author, 1683) [Table 122], 17. 
claims. Yet, the most important point here is that an English editor, translator, and printer all thought that this work, including its defense of David George, merited publication. Certainly there were Quakers who would have found comfort in knowing that they were not alone in promoting the Spirit within as divine authority. This was, moreover, part of a Europe-wide phenomenon, as Joris's ideas and reputation were being positively reconsidered by a variety of Pietists and freethinkers who valued the inner Word, a creative approach to scripture, and the depreciation of belief in malevolent spirit beings. ${ }^{147}$ In this translation of Kuhlmann, we catch a glimpse of it in England. But it and Penn's work are drops in the bucket compared to polemics condemning Joris as the founder of diabolical libertinism, materialism, and atheism of the seventeenth century. That said, the activity of the Hartlib circle to find detailed information on Joris was not, it turns out, for entirely negative reasons. The translator of the Matthew Wier book was Daniel Foote, a medical doctor who was associated with the famed Flemish alchemical scientists Franciscus van Helmont and his son Franciscus Mercury van Helmont and who translated the latter's works for an English audience. ${ }^{148}$ These natural philosophers were also unconventional in their religious outlooks - some, such as Foote and Franciscus Mercury van Helmont associating with the Quakers—and their quest for reliable information on Joris seems, in fact, to have been part of the movement to rehabilitate earlier spiritualists like Joris and Wier as a way of counteracting the negative polemics still making life difficult for late seventeenth-century mystics and Quakers.

Most spiritualists opposed both heresy and witch-hunting, especially those who followed Joris's depreciation of the diabolical, such as the Doopsgezinden mentioned above who published treatises emphasizing the impotence of the devil and the lack of any real danger from witchcraft. ${ }^{149}$ Even though they were a minority group, the Doopsgezinden shaped opinions on the inter-

\footnotetext{
147 Arnold, Unparteyische Kirchen- und Ketzer-historie (see above, n. 9); Vinke, De Zilvere Arke (see above, n. 9). See esp. Douglas H. Shantz, "David Joris, Pietist Saint: The Appeal to Joris in the Writings of Christian Hoburg, Gottfried Arnold and Johann Wilhelm Petersen," Mennonite Quarterly Review 78 (2004), 415-432.

148 David Thorley, "Daniel Foote, M.D., of Cambridge: The Evidence in Print and from the Sloane Collection," Electronic British Library Journal (2013, article 15), 1-30. I am thankful to William Miller for pointing me to this article.

149 See Waite, "Knowing the Spirit(s)" (see above, n. 6), 42-45 and the literature cited there.
} 
secting issues of religious toleration and depreciation of the devil; theirs were the principal works of demonology written by Dutch authors. Spiritualism thus played an outsized role in shaping Dutch demonological theory and the Dutch Republic's turn away from witch-hunting, as noted above. Another intellectual who imbibed of such currents was the Catholic priest and professor Cornelius Loos of Gouda. In 1593 he was forced to recant a number of positions when his manuscript against the witch-hunts was confiscated in Trent during a witch panic there. Among his controversial ideas was the denial that the devil had any real place in the natural world, in Clark's words "a far more daring step" than any taken by Wier. ${ }^{150}$ While it is dangerous to speculate in the absence of clear evidence, the fact that Loos came from Gouda is intriguing, for here spiritualism flourished. Just a few years after Loos was forced to leave the city in 1574 when it fell to the Reformed, Herman Herberts was installed preacher in 1582. A former Catholic monk from Westphalia, Herberts was expelled from city after city for his anti-confessional views but found a warm welcome in Gouda where he remained preacher until his death in 1607 . His own publications reveal that he had adopted Joris's demonology, and was not afraid to admit to admiring Joris's ideas. ${ }^{151}$ Gouda was, in other words, a largely Catholic city happy with religious diversity, tolerance, and non-confessionalism thanks to spiritualism. ${ }^{152}$ Loos also appreciated Wier's arguments (a dangerous position to admit during the height of the witch-hunts in Germany), and for him to have imbibed of spiritualism's skeptical currents toward the devil would therefore not be surprising, although he was no friend of the Reformed. As Clark has argued, Protestant writers were so afraid of spiritual apostasy because it implied no real contact between humans and devils; "the only logical alternative left was to remove devils from the physical world altogether and turn spiritual demonism into a metaphor," something that Loos, inspired by Wier and indirectly by Joris, seems to have done. ${ }^{153}$ The Dutch preferred the impotent demons of Joristic spiritualism.

Joris's Reformed opponents also helped inadvertently to disseminate Joris's demonology by simplifying it as they explained its dangers. Others actively defended it, and Joris's anti-devil works were reprinted through the first quarter of the seventeenth century. Joris's ideas were so well known in the Dutch

\footnotetext{
150 Clark, Thinking with Demons (see above, n. 103), 211.

151 Waite, "Man is a Devil" (see above, n. 6).

$15^{2}$ Its major church avoided the iconoclasm seen elsewhere. On the Dutch religious scene in general, see the essays by Benjamin J. Kaplan, Reformation and the Practice of Toleration: Dutch Religious History in the Early Modern Era (Leiden, 2019).

153 Clark, Thinking with Demons (see above, n. 103), 211.
} 
world that critics of Balthasar Bekker could merely cite Joris's name, along with those of Thomas Hobbes and Baruch Spinoza, as principal sources for Bekker's denial c. 169 o that demons had a place in the natural world. As noted above, while no Dutch writer published a treatise promoting witch-hunting, several composed works against the activity, and all of these were influenced by the region's spiritualistic currents, from Wier and Loos, to van Dale. Many Dutch were quite familiar with the idea that demons did not exist in the natural world. The English did not have this debate until around the time when references to Blesdijk's Life and Doctrine of David Joris appeared in the late 1640s. According to Alexandra Walsham, seventeenth-century English Protestants were indeed engaged in a major debate over angels, but only on the issue of their representation in churches, as Puritans sought to remove images of angels from places of worship to avoid any hint of Catholic idolatry, against orthodox Anglicans who sought to retain them. ${ }^{154}$ The idea that the devil was not a real being therefore took longer to penetrate the mental world of England and Scotland, and when writers such as Baillie stumbled upon it, they expressed real shock.

\section{Muggletonian Demonology}

There is thus the possibility that the sudden surge in polemical attacks on Joris's demonology in England in the later 1640s helped spread the very idea that orthodox writers were attacking. The idea of an internalized devil may, however, have entered English debates through the translations of other continental mystics, such as Jacob Boehme. For example, in 1983 Christopher Hill expressed puzzlement at some of the doctrines developed by the idiosyncratic Muggletonians, especially their concept of angels and demons in which, as Lodowick Muggleton's fellow prophet John Reeve declared, there was no devil "but what dwells within the bodies of men and women."155 In Reeve's words:

I declare from the Holy Spirit, that there is no Devil at all without the body of man or woman, but what dwells within the bodies of men and women; so that, that Devil so frequently spoken of in the letter of the Scripture, that tempts men and women to all unrighteousnesse, it is mans

154 Alexandra Walsham, "Angels and idols in England's long Reformation," in Marshall and Walsham, Angels in the Early Modern World (see above, n. 93), 134-167.

155 Christopher Hill, "John Reeve and the Origins of Muggletonianism," in The World of the Muggletonians, ed. Christopher Hill, Barry Reay, and William Lamont (London, 1983), 64110. 
spirit of unclean reason, and cursed imagination, that unsatiably lusteth after things that perish; until the Holy Spirit of faith enters into the man, and purifies his unclean spirit, and reveals unto his dark understanding spiritual and glorious durable things ... ${ }^{156}$

This demonology sounds virtually identical to that of David George as presented by his opponents. Hill's surprise at the idea likely arises from the fact that this internalized devil had only been implicit in the Familists' alleged emphasis that hell was on earth. Hill had argued that "Reeve's doctrine seems to have been taken straight from Jacob Boehme, many of whose works were translated into English in the 1640s: Muggleton at least was reading him in the early fifties." Reading Boehme, however, reveals that his demonology was not as fully internalized as the Muggletonians had it. Instead, Boehme wrote that humans need to learn "to know our selves, because the Devill dwelleth with us in this world, who is both Gods Enemy and ours, and daily misleadeth us ..." and that the devil is "our own enemy Self, which our first parents awakened and purchased for us, which we carry within us, and which we our selves now are." Then, as Boehme describes the origin of demons, he refers to the "bodifying" of devils and angels, in the process making it clear that he does ascribe some external reality to them. ${ }^{157}$ On the other hand, Joris's demonology as described by his opponents explicitly denied any such external existence for these spirits. Reeve and Muggleton began their movement shortly after a series of visions in 1651; this was, of course, at the height of the debate over David George's demonology placing demons and angels within each human's conscience. The closest parallel and potential influence then for the Muggletonian demonology was Joris's as presented in the English press.

Other nonconformists similarly internalized the devil at precisely the time that Joris's demonology was made known: Gerrard Winstanley in 1650, Jacob Bauthumley in 165o, Theaurau John Tany in 1651, and John Webster in 1653, the last phrasing this in ways remarkably similar to David George: "there is no greater Deceiver to be found then is within Man: No cunninger Devil, no greater ANTICHRIST, nor no worse wiTCH then what Man hath in his own heart."158

156 [John Reeve], A Transcendent Spiritual Treatise (London: for the authors, [1651]), 24.

157 Jacob Behmen, The Second Booke. Concerning The Three Principles of The Divine Essence Of the Eternall, Dark, Light, and Temporary World. Shewing What the Soule, the Image and the Spirit of the Soule are; as also what Angels, Heaven, and Paradise are. How Adam was before the Fall, in the Fall, and after the Fall. And What the Wrath of God, Sinne, Death, the Devils and Hell are ... (London: for H. Blunden, 1648), fols. $\mathrm{a2}^{\mathrm{v}}-\mathrm{a} 3^{\mathrm{r}}, 10,25^{-26 .}$

158 John Webster, The judgement set, and the bookes opened. religion tried whether it be of god or of men. the lord cometh to visit his own, for the time is come that judgement must begin at 
Webster does not cite Joris, but then very few of those who took up his ideas ever did.

Hill furthermore concluded that such radical ideas as internalized spirit beings, the "inner light," mortalism, and anti-trinitarianism became part of learned discourse in some form in works by John Milton, John Locke, and Isaac Newton, among many others. ${ }^{159}$ David Como has recently commented that, despite being the preserve of small groups of "separatists and Anabaptists" before 1640 , the

sudden removal of episcopal oversight, coupled with the furiously contested conditions of civil war, allowed these tiny groups to pour their ideas into the public domain with evangelical zeal. The result was fierce controversy, but also the rapid spread of these doctrines and practices outward into the broader godly community; once again, the ideas and impulses were decoupled from their original carriers, who were forced to watch (sometimes in horror) as enthusiasts carried treasured doctrines in new directions, splicing them together with alien traditions or influences ... ${ }^{160}$

What happened in England after the Restoration of 166o was not unlike the situation in the Dutch Republic decades earlier: the ideas of nonconformists, mystical and otherwise, continued to inform the currents of thought at all levels, forcing the reevaluation of traditional interpretations and doctrines, despite the fulminations of learned orthodox writers against them. Those very fulminations helped, in fact, to spread the unorthodox ideas more widely than the writings of nonconformists ever could; this is certainly true for Joris, whose writings were not available in English.

the house of god. to separate the sheep from the goats. and the precious from the vile. and to discover the blasphemy of those that say, they are apostles, teachers, alive, rich, jewes, but are found lyars. deceivers. dead. poore, blind, naked. the synagogue of satan. in severall sermons at alhallows lumbard-street, by john webster, a servant of christ and his church (London: for R. Hartford, 1654), 159. For this and these other references, see S.F. Davies, "The Reception of Reginald Scot's Discovery of Witchcraft: Witchcraft, Magic, and Radical Religion," Journal of the History of Ideas 74 (2013), 381-401, there 397-398.

159 Hill, "John Reeve and the Origins of Muggletonianism" (see above, n. 154). See also Christopher Hill, Milton and the English Revolution (New York, 1977).

16o Como, "The Family of Love" (see above, n. 16), $5^{84}$. 
What then can we conclude from this survey of the reception of the "Devil of Delft" in English polemics? First, the cross-Channel communication between the Netherlands and England was a significant factor in shaping English perspectives on their own religious differences and conflicts. Yet, it has become obvious that the English were greatly hampered by their lack of linguistic ability in Dutch or German. They thus had to rely on the few works about Joris that were available in Latin or wait for Dutch translators to produce English editions. The Basel pamphlet in particular exerted an influence far above any other source on the subject. English writers thus relied heavily on this very limited perspective of Joris's ideas which excluded any clear reference to his demonology. Catholic writers pounced on the Basel version of the Joris story to associate all Protestants with Joris's apostasy. Additional works cited by Protestant writers, such as Bullinger and Micron, similarly relied heavily on the Basel pamphlet. No English polemicists were able to read Joris for themselves, which might have given them a more sympathetic evaluation of some of his ideas. Reading Joris, as Dutch Protestants did, would have also made the English aware of the unusual Joris demonology much sooner. Instead, this remained in the background until the 1640 s.

Second, since English writers knew so little of the "real" Joris, they could fashion him in ways to suit their own polemical interests. Joris acted as the perfect foil for the dangers of Protestantism taken to its logical extreme. Or, he could be pressganged into counteracting the growing attraction of antitrinitarianism by linking this to the spiritualistic fanaticism of the notorious Joris, with his claims of being Christ, his alleged sexual improprieties and support for polygamy, and his supposed atheism. Joris thus acted as a warning against not just those who rely on the Spirit within for their religious authority, but for any seeking to dissent from orthodoxy, whether that is Anglicanism, Reformed Protestantism or Puritanism, or Presbyterianism. And, with the slander that Joris had apostatized against Christianity and converted to Judaism or, more frequently, "turned Turke," he could even be used as a foil against Islam or Judaism as these faiths were being reevaluated in the seventeenth century. The lack of first-hand information about or by Joris made him much more useful in this regard than Hendrik Niclaes whose writings were translated and whose supporters could respond to such slanders. Joris had neither.

Third, and most strikingly: one important, neglected factor in the difference between the Dutch Republic and Britain during the seventeenth century was the fact that the former ended witch-hunting quite early, moving against formal trials in the last decades of the sixteenth century, while England was enrap- 
tured by them until c. 1650 and Scotland into the eighteenth century. In the Netherlands, the idea that the devil may not exist in any external fashion had become a commonplace, thanks to the debate over Joris's demonology. Many within the nonconformist streams, such as the liberal Doopsgezinden, actively promoted the impotence of the devil and the irrationality of the diabolical witch stereotype, and their views helped shape those of Bekker. The English did not have this debate until after the publication of Blesdijk's Life and Doctrine of David Joris in 1642, as seen in the shocked reaction of the Scottish minister Baillie when he came across it. It surely is no coincidence that a number of English nonconformists began suggesting that demons existed only as one's inner temptation at the same time as this discovery of Joris's demonology.

While the tendency in scholarship is to attribute the death of the devil to Cartesianism and the Enlightenment, we need also to give credit to the writings of the Dutch spiritualist David Joris and to the debate that these aroused. It seems safe to suggest that the reaction of English polemicists when around 1647 they became fully cognizant of Joris's views on the powerlessness of the devil indicates that had they known it beforehand, they would have attacked it with the kind of vigour their Dutch coreligionists had been showing since the sixteenth century. Those attacks in the Dutch context helped unintentionally to promote a skepticism about the interference of the devil in human affairs. I suggest here for further discussion the possibility that the lack of such debate in the British Isles allowed witch trials to proceed apace until the late 1640 s when David George's demonology became a matter of controversy, attracting some, repelling many, but giving readers of English polemics enough pause to reconsider the reality of diabolical witchcraft. 


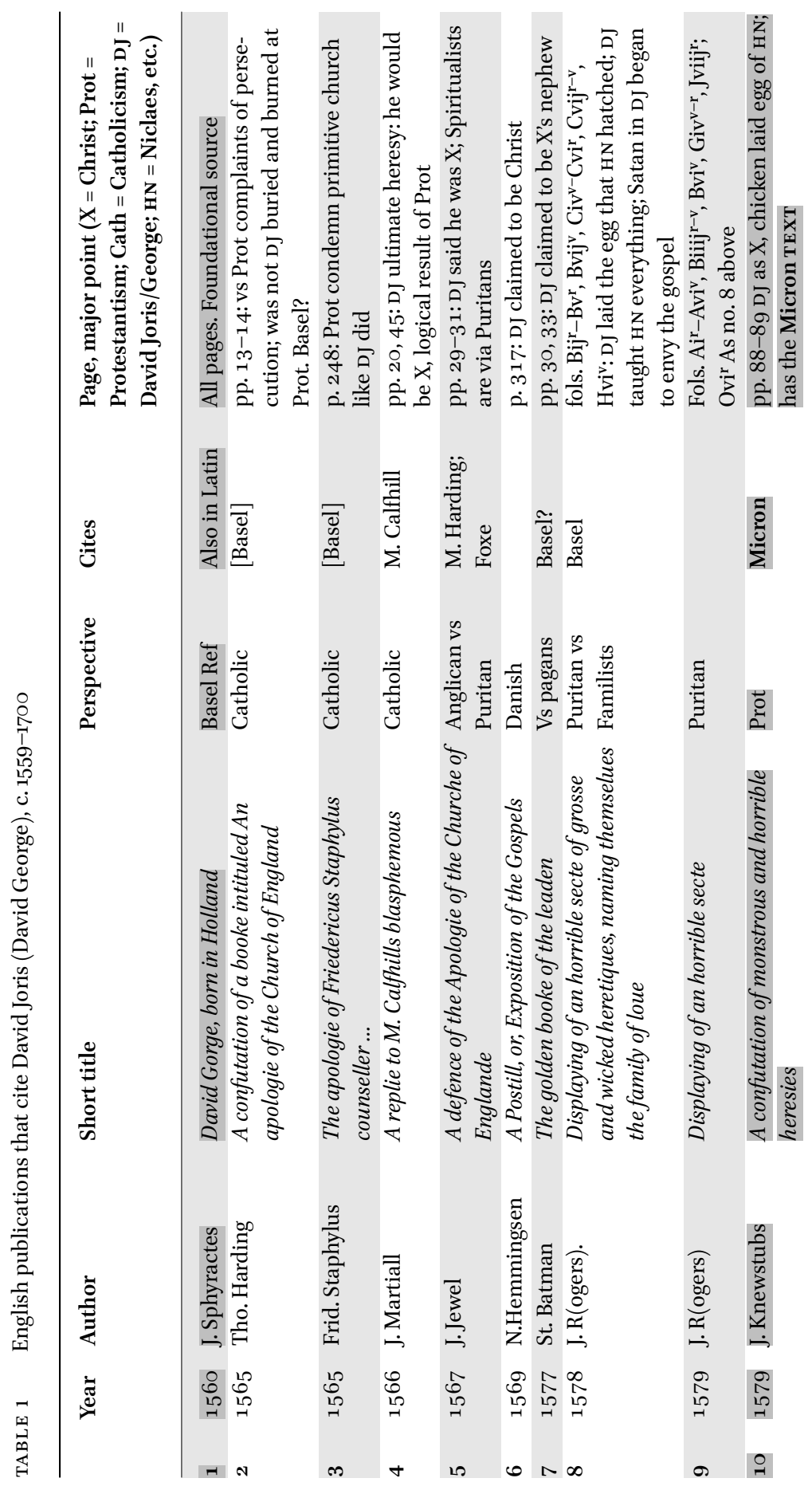




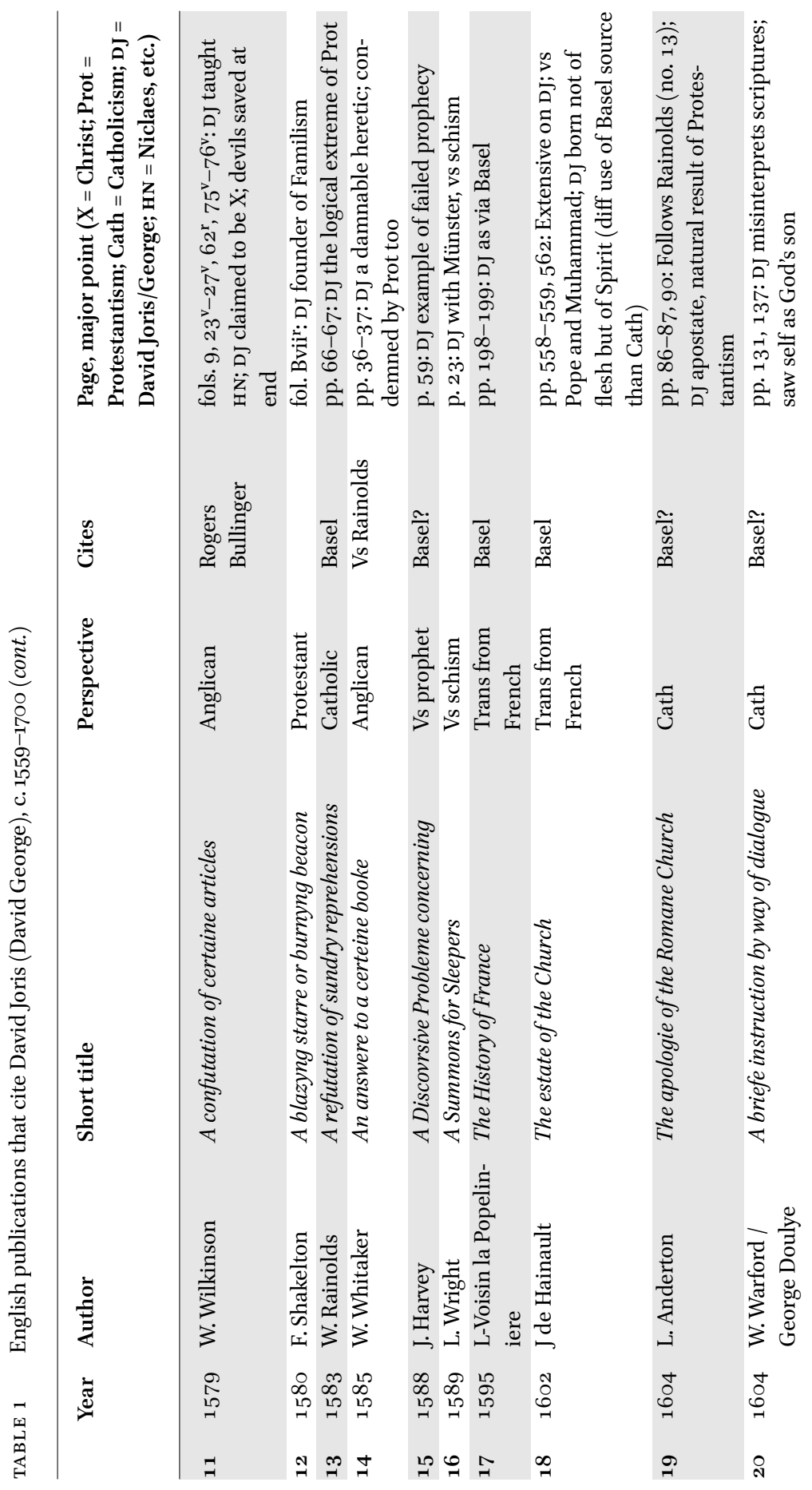




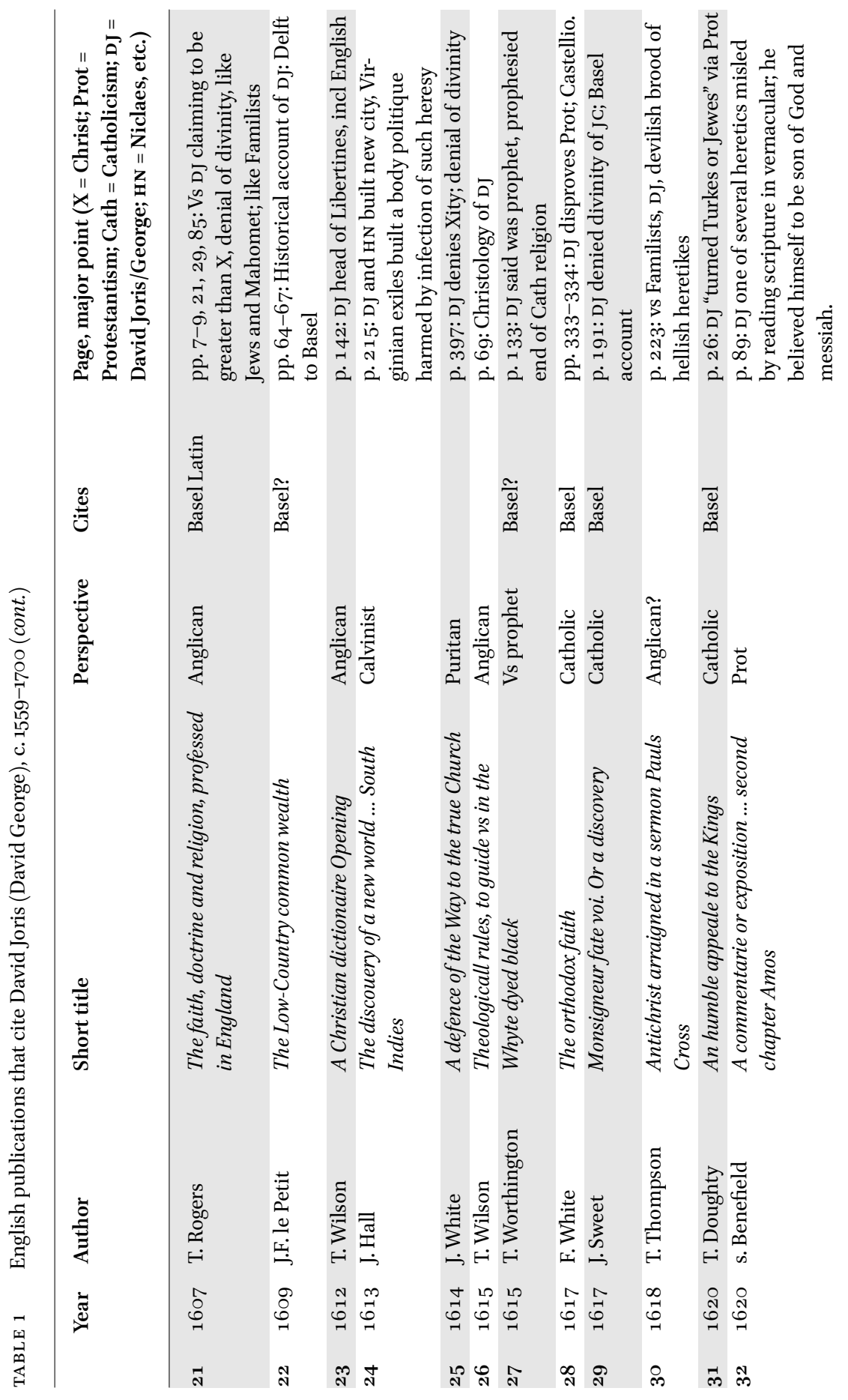




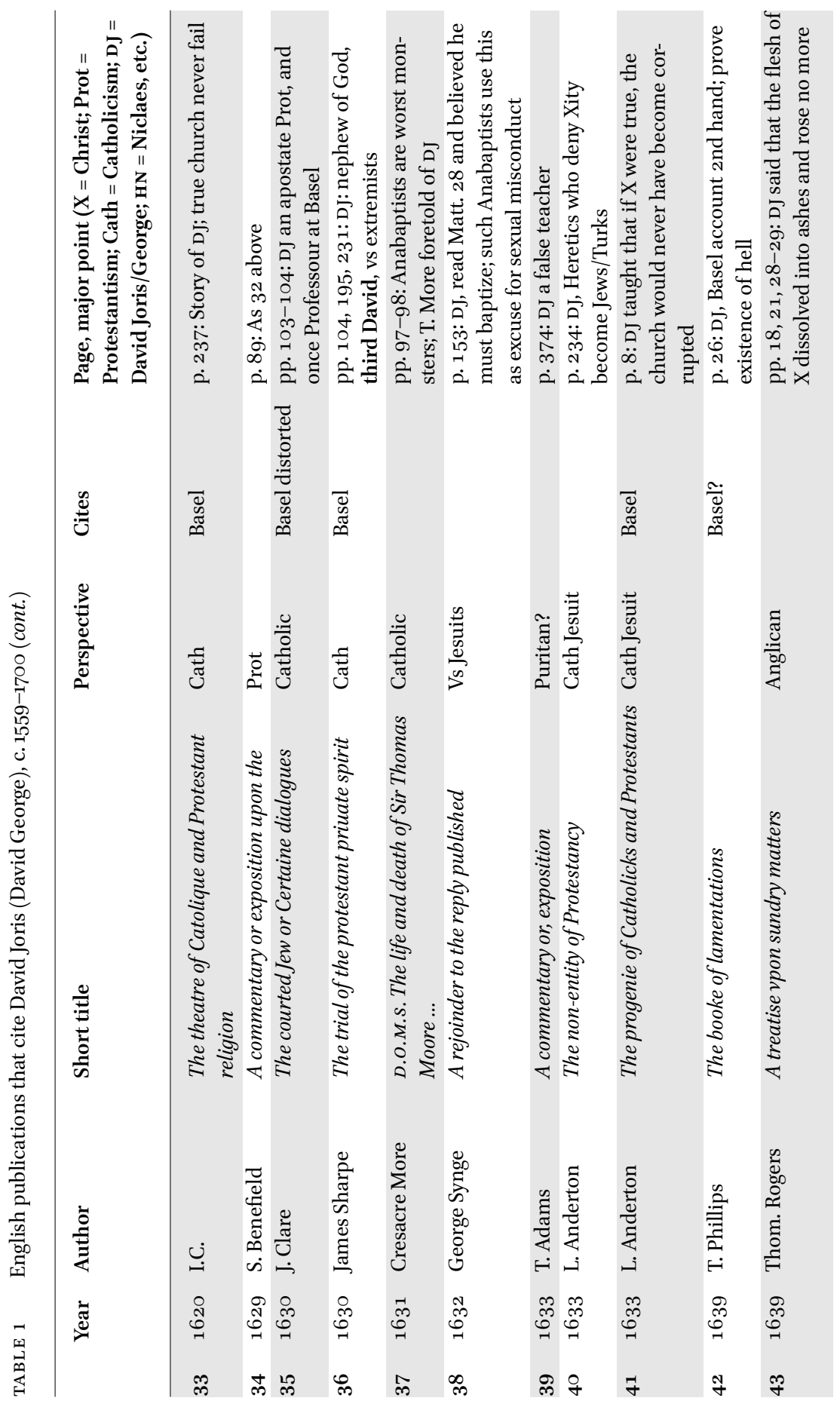




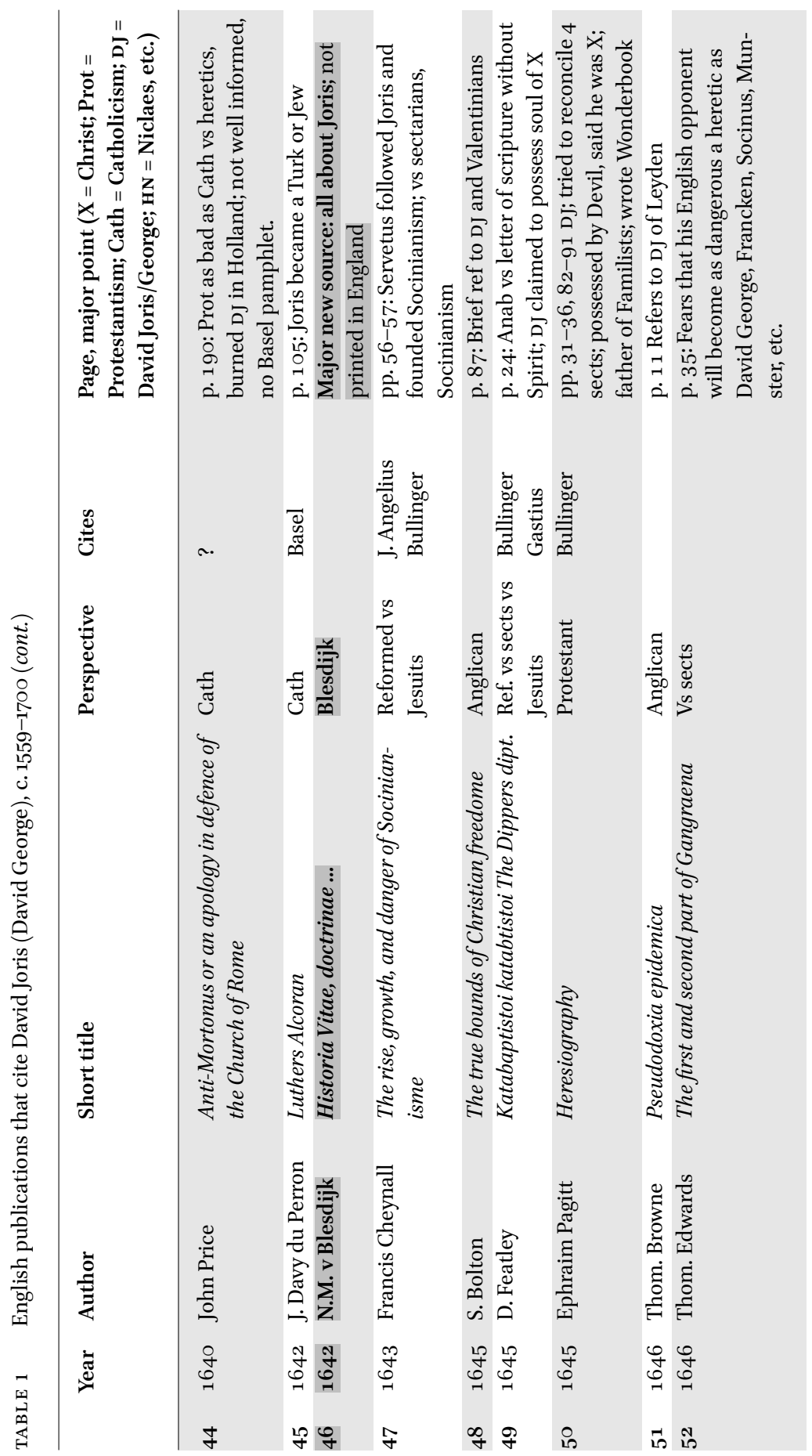




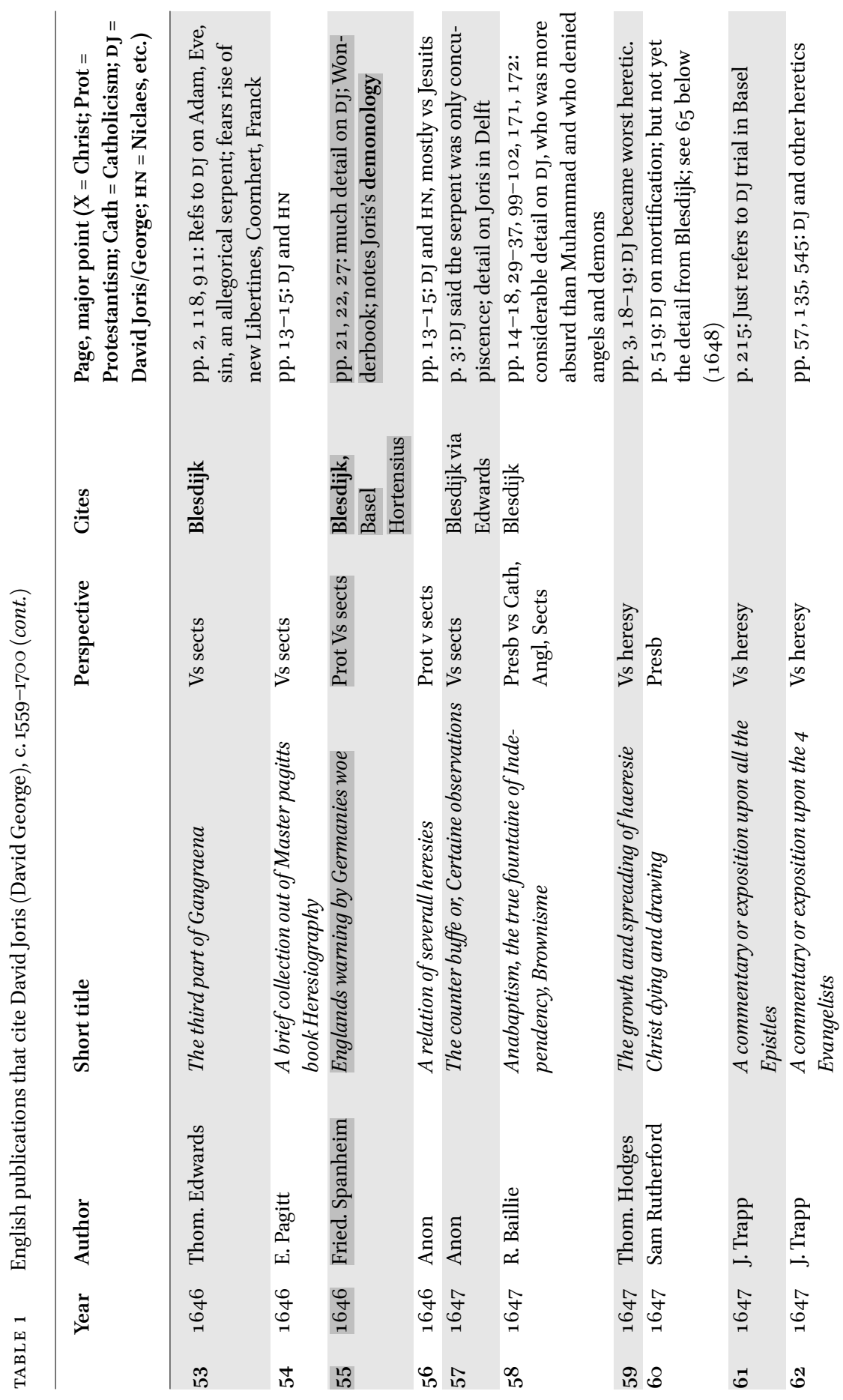




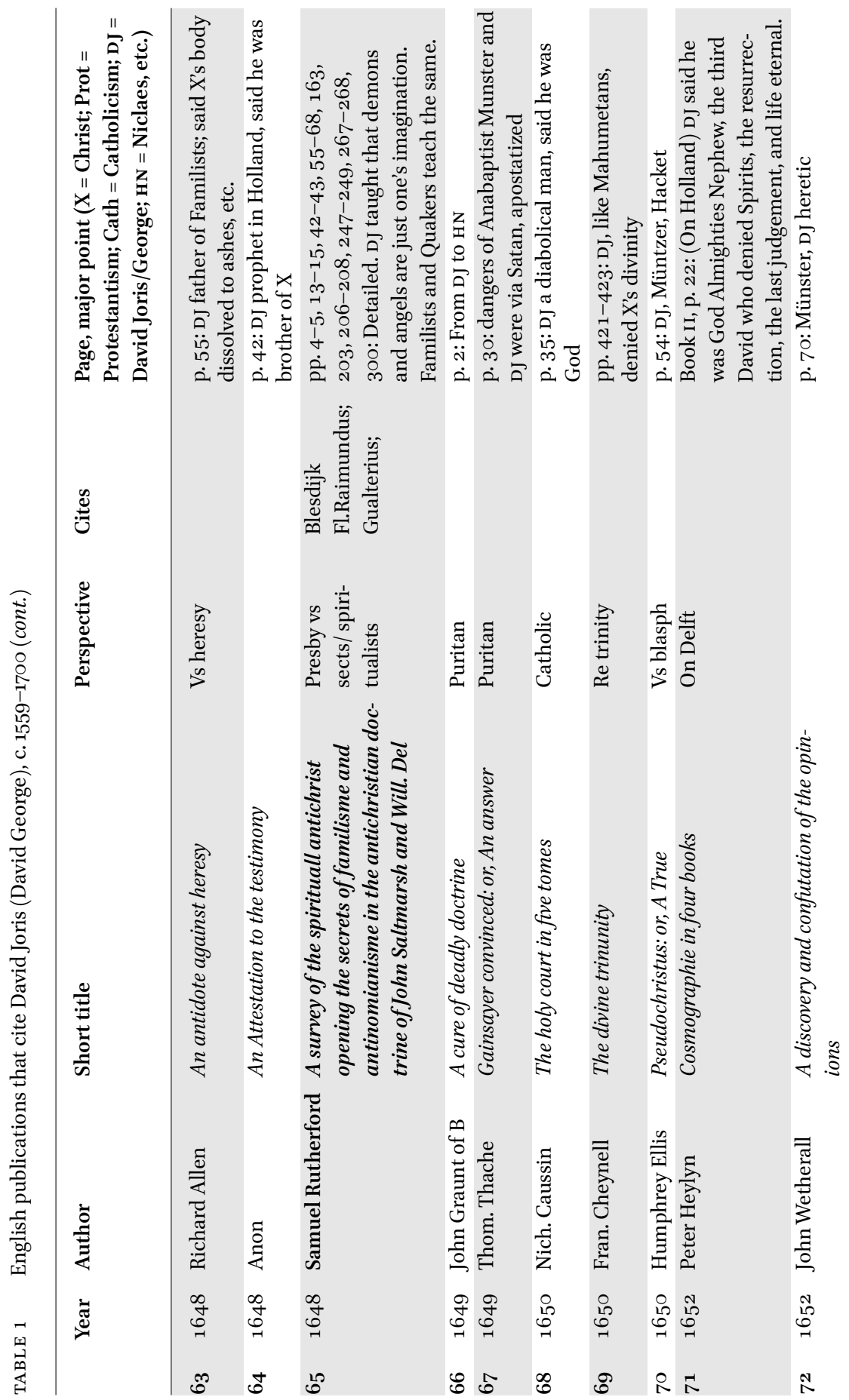




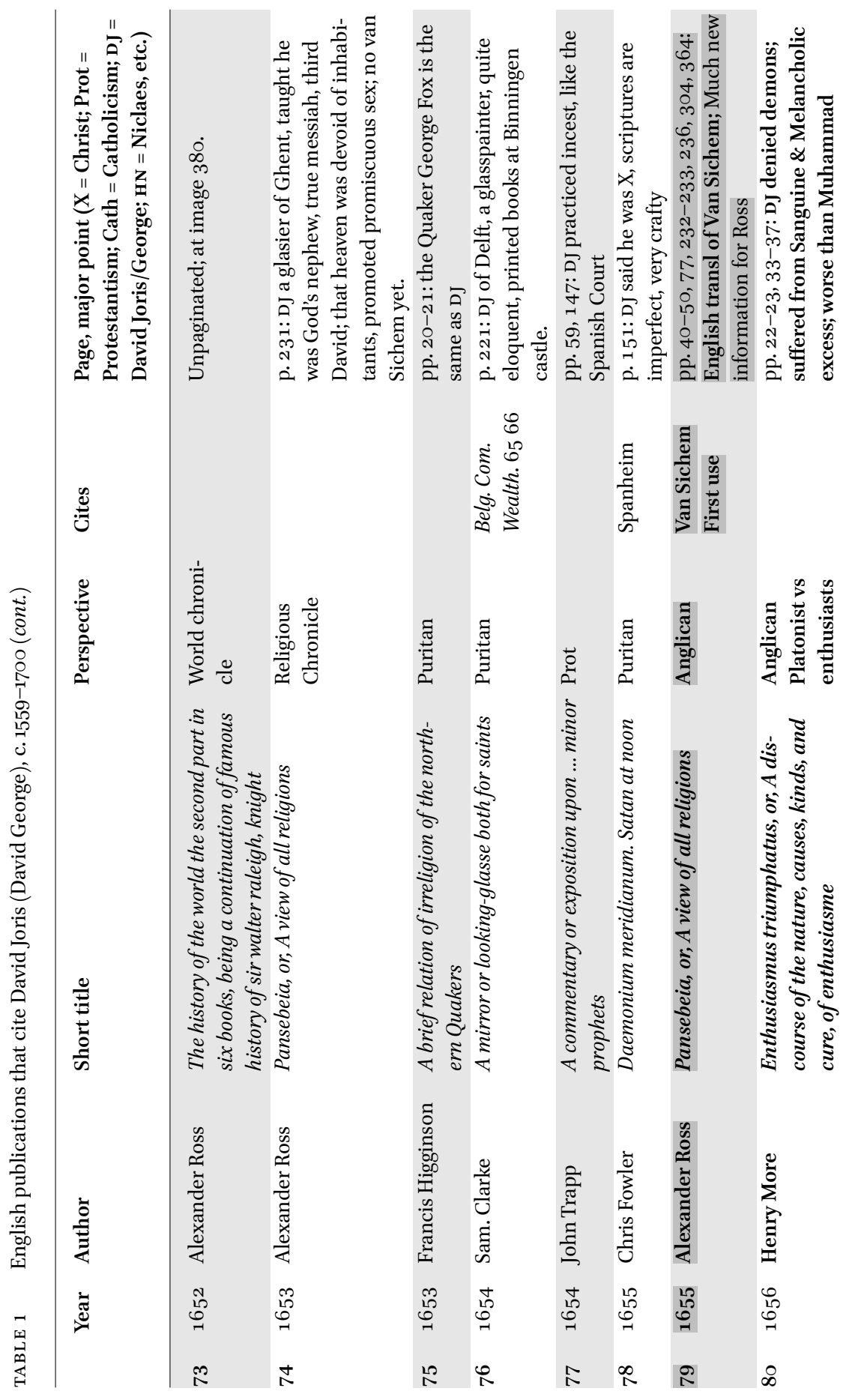




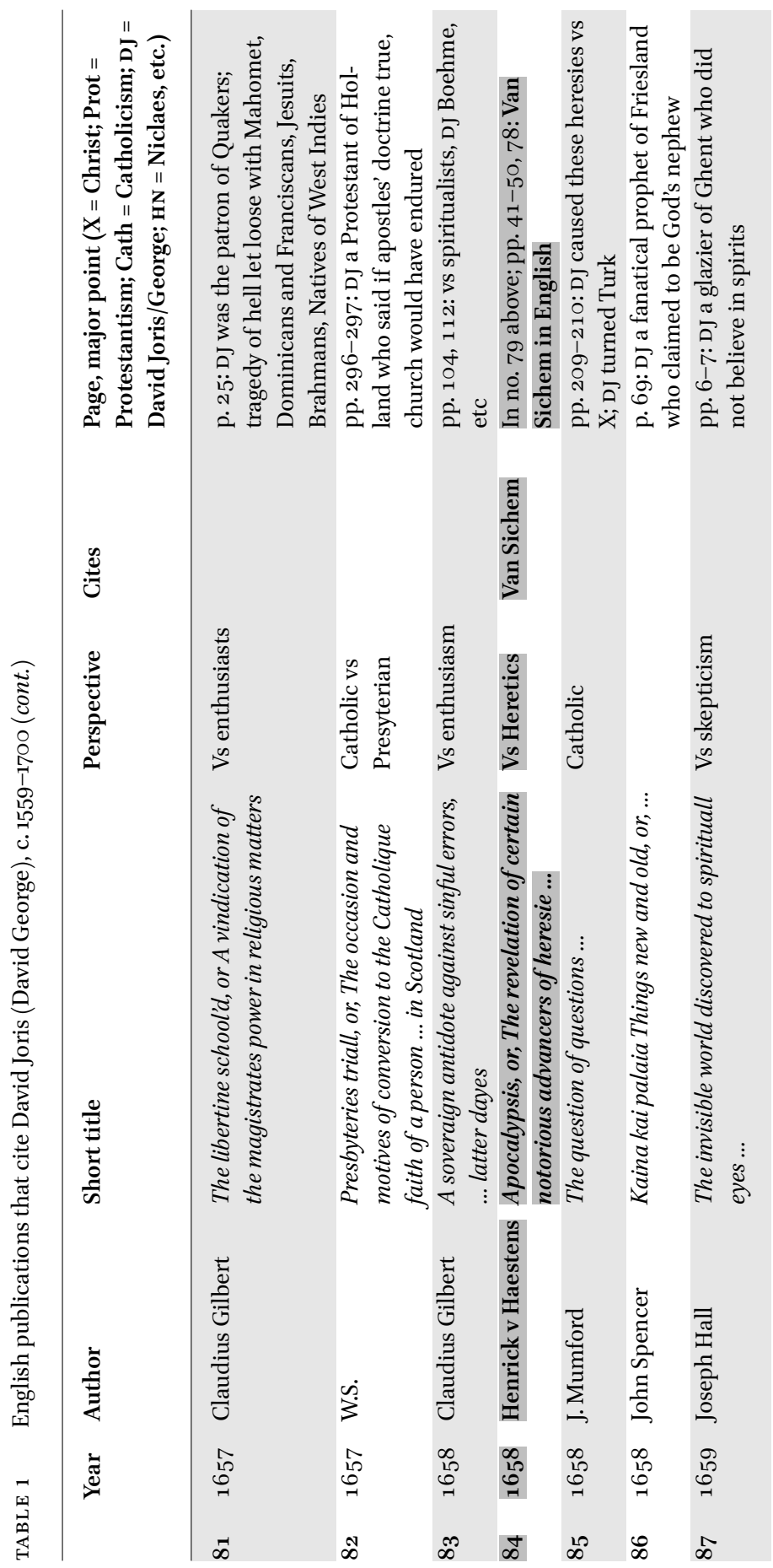




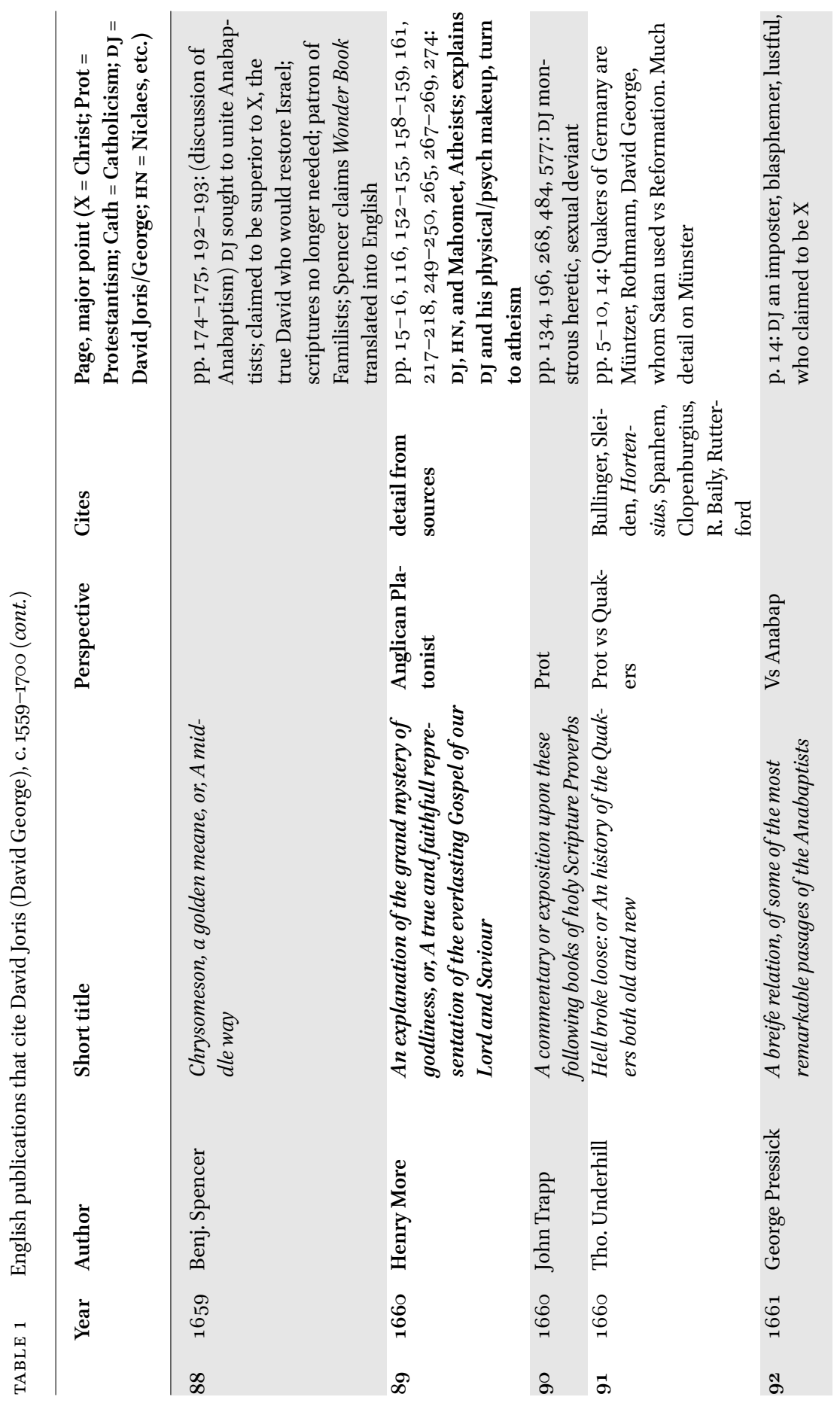




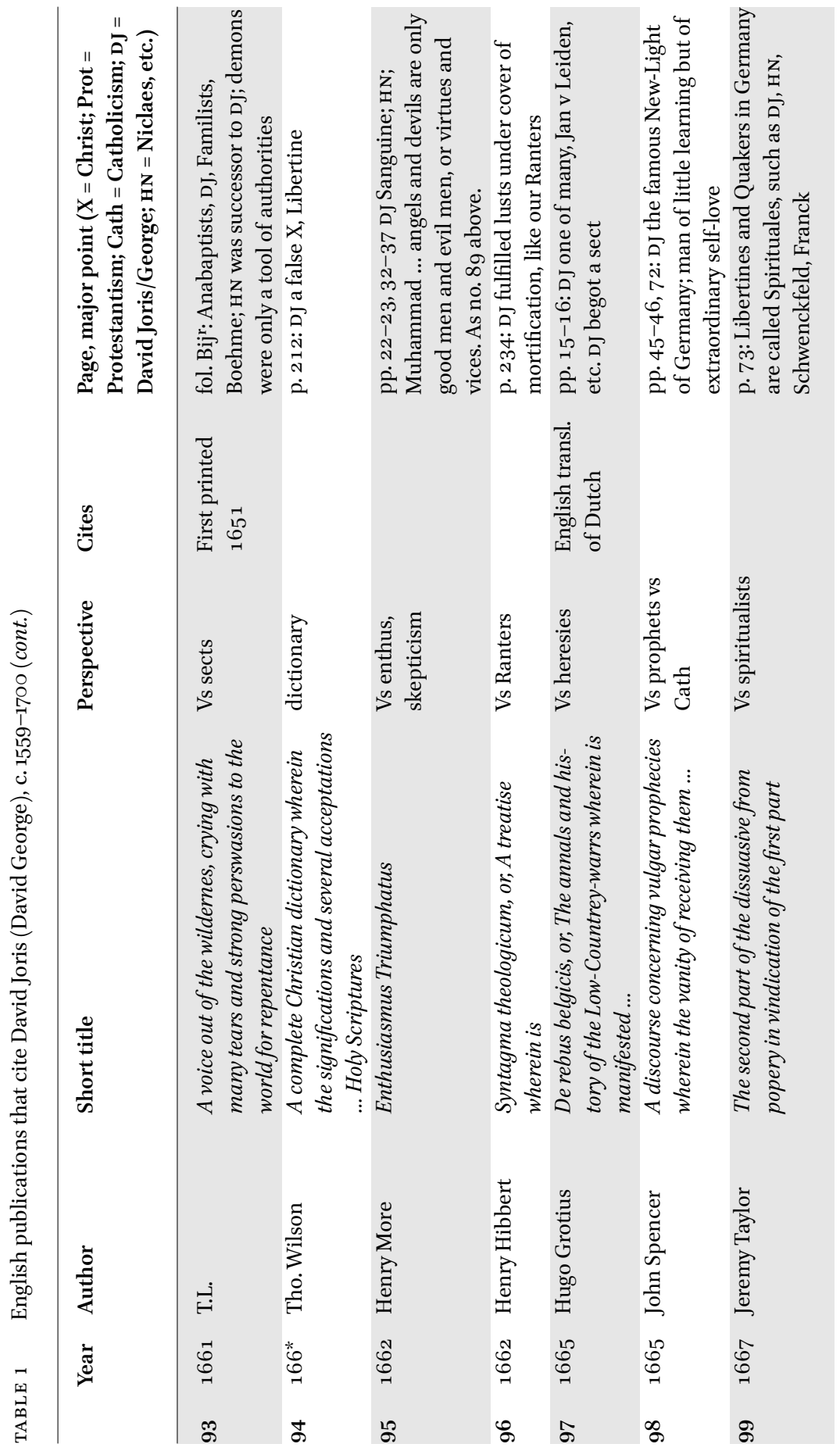




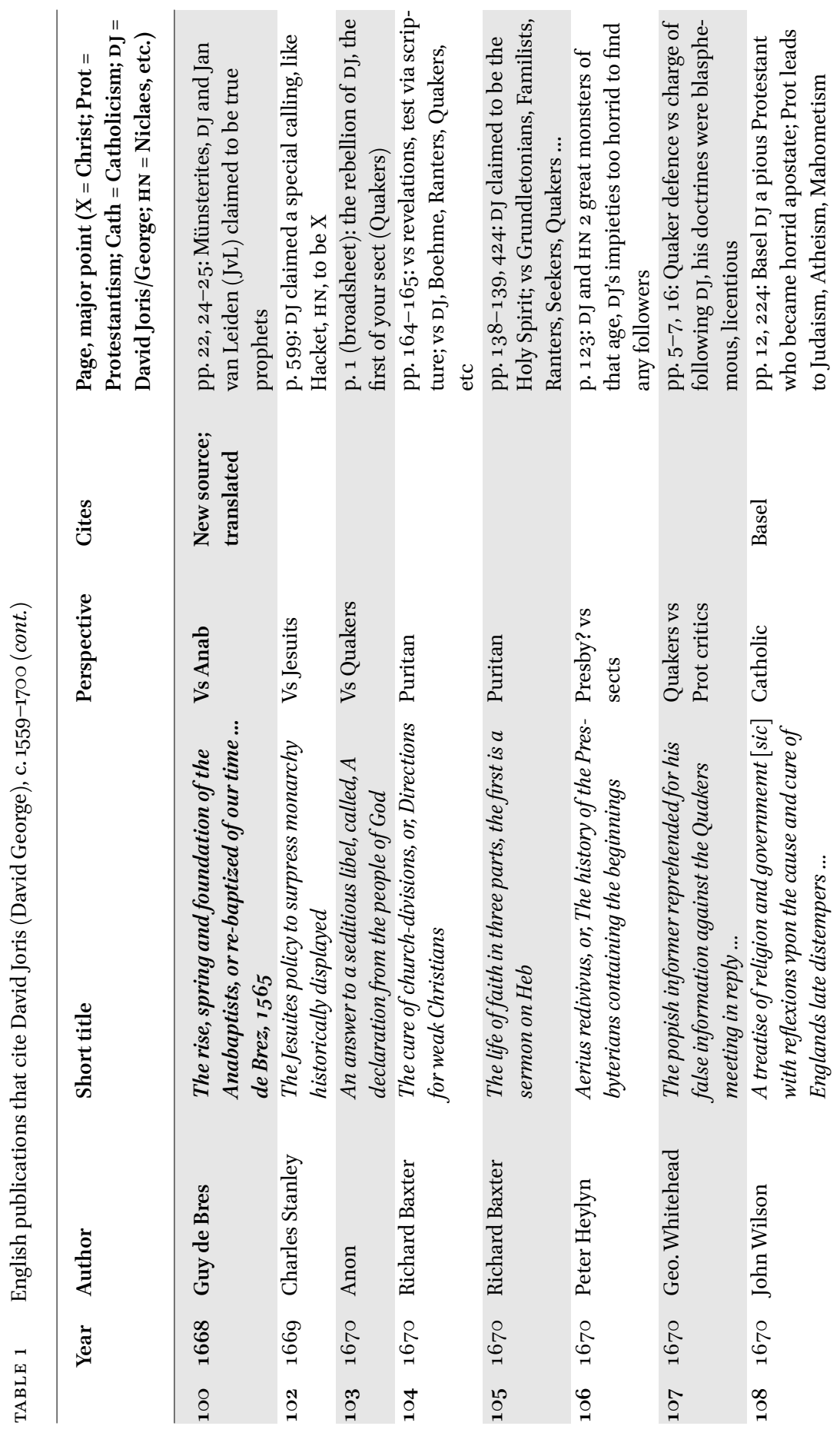




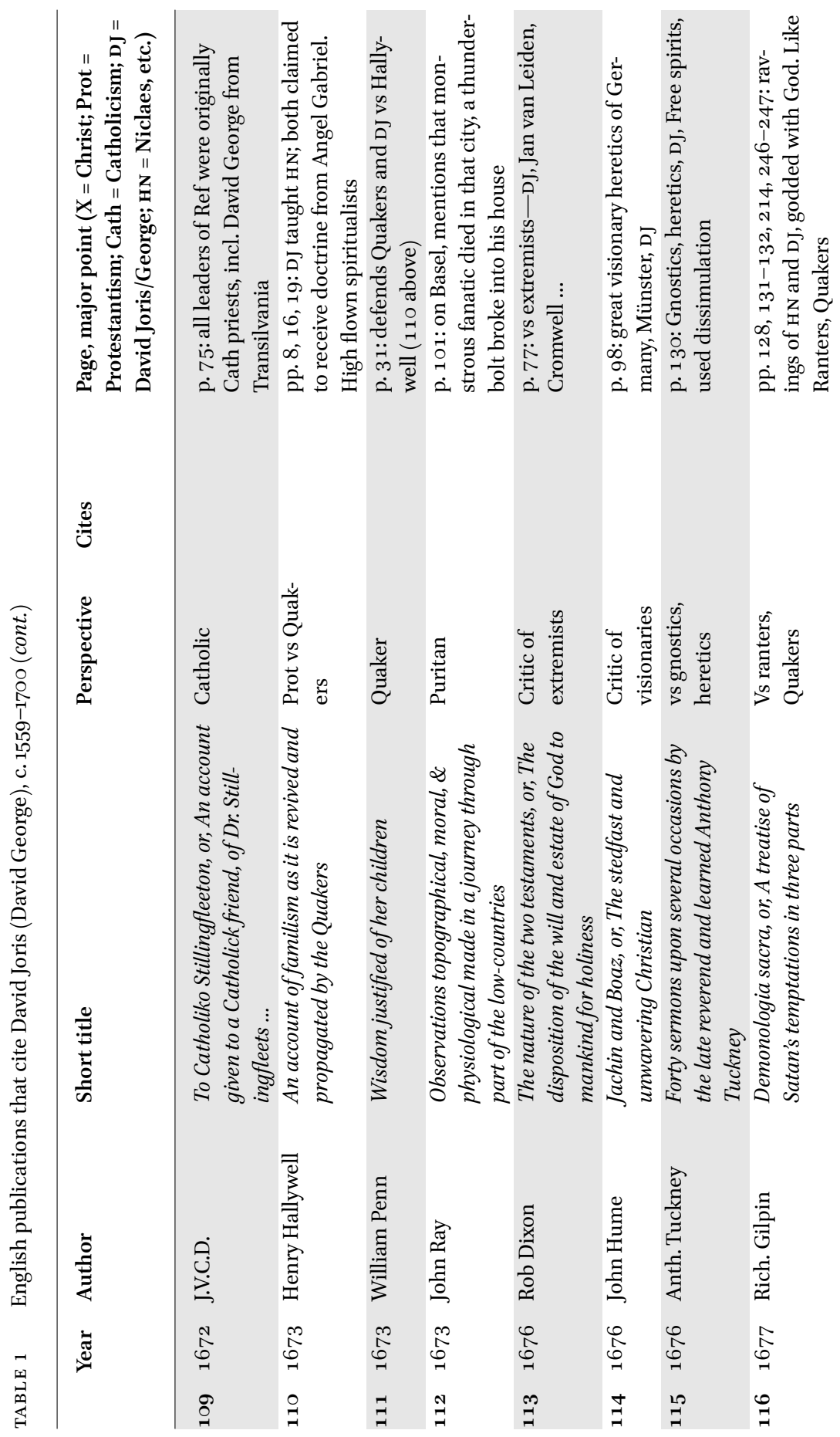




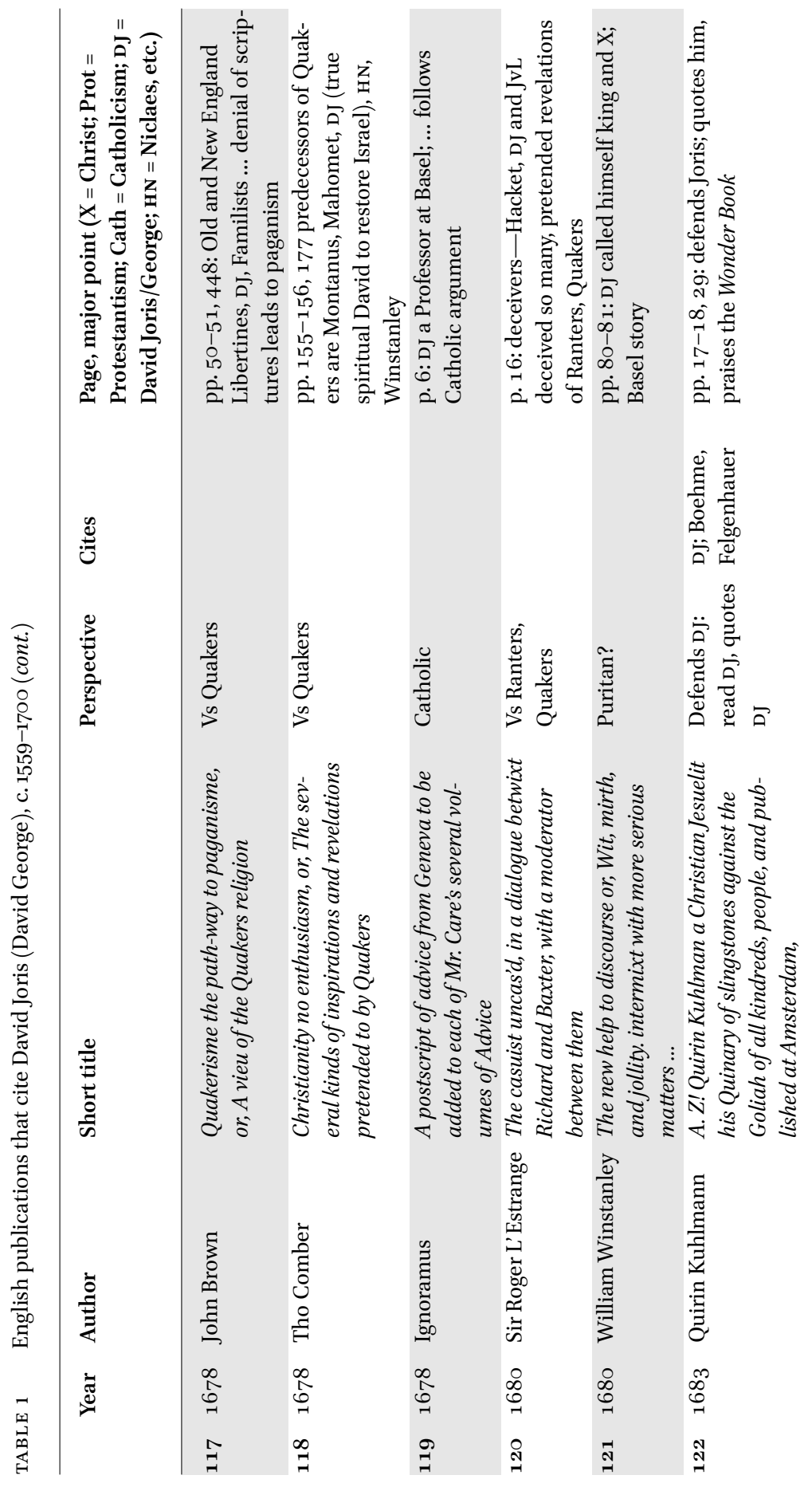




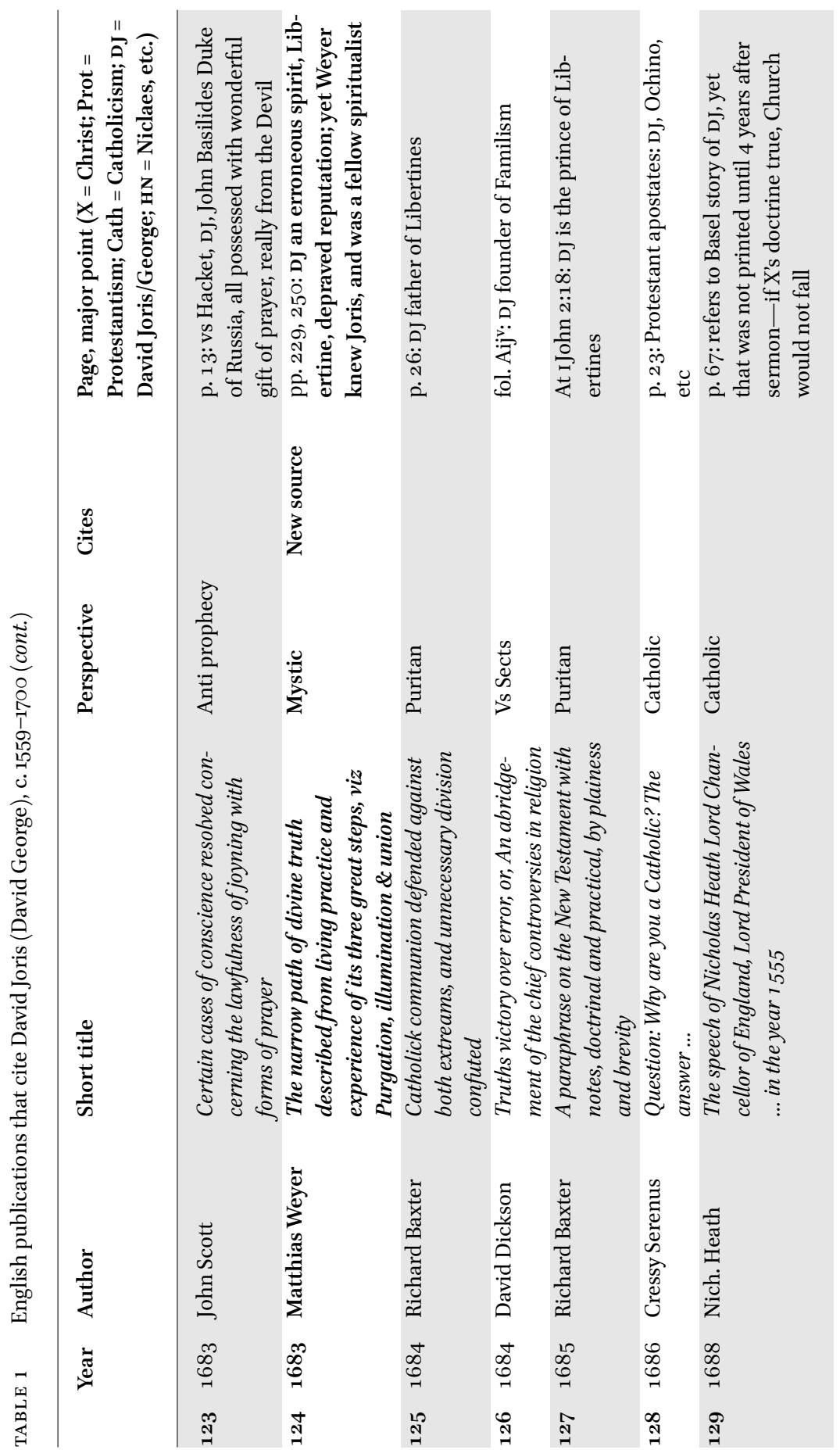




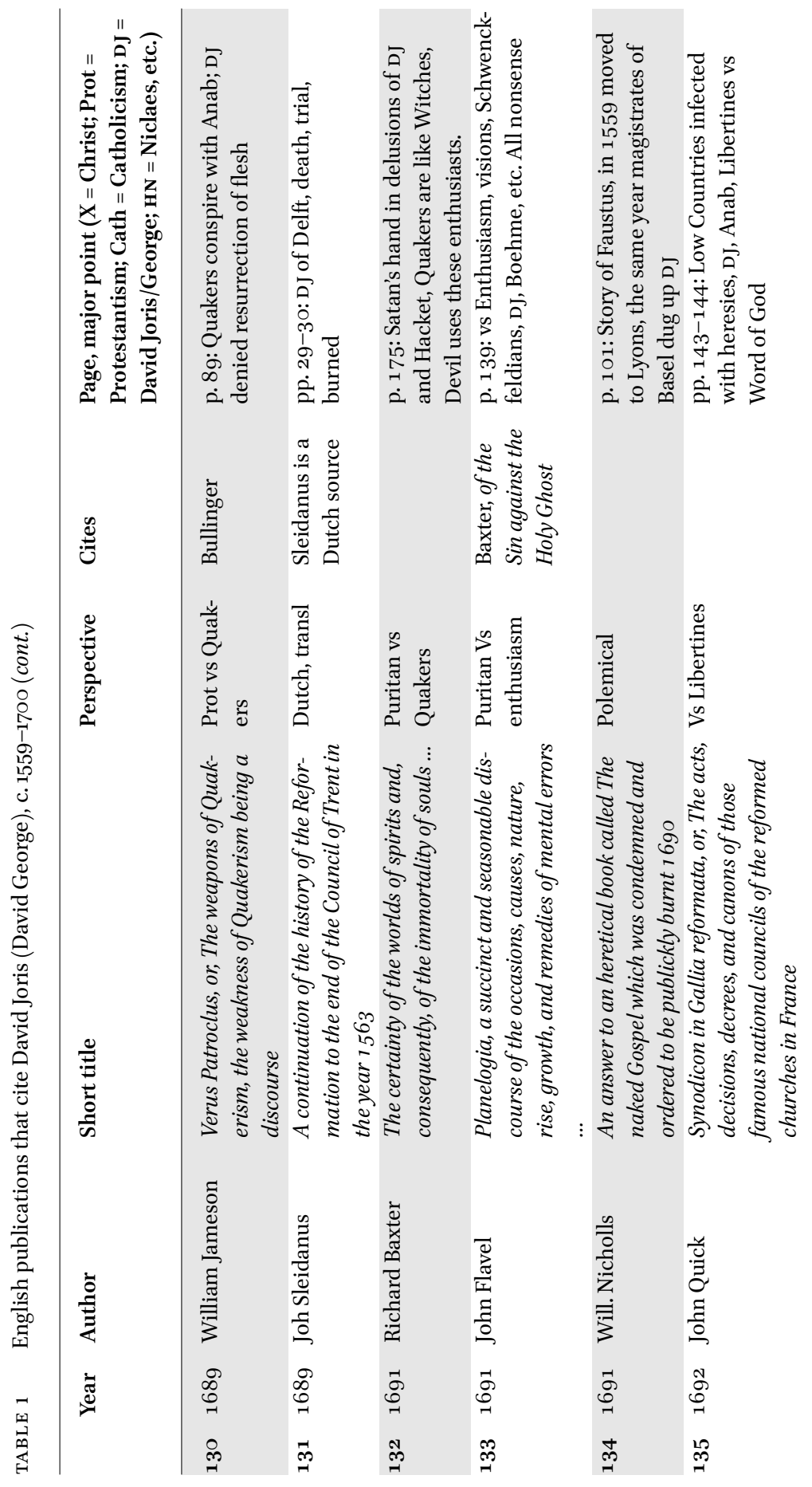




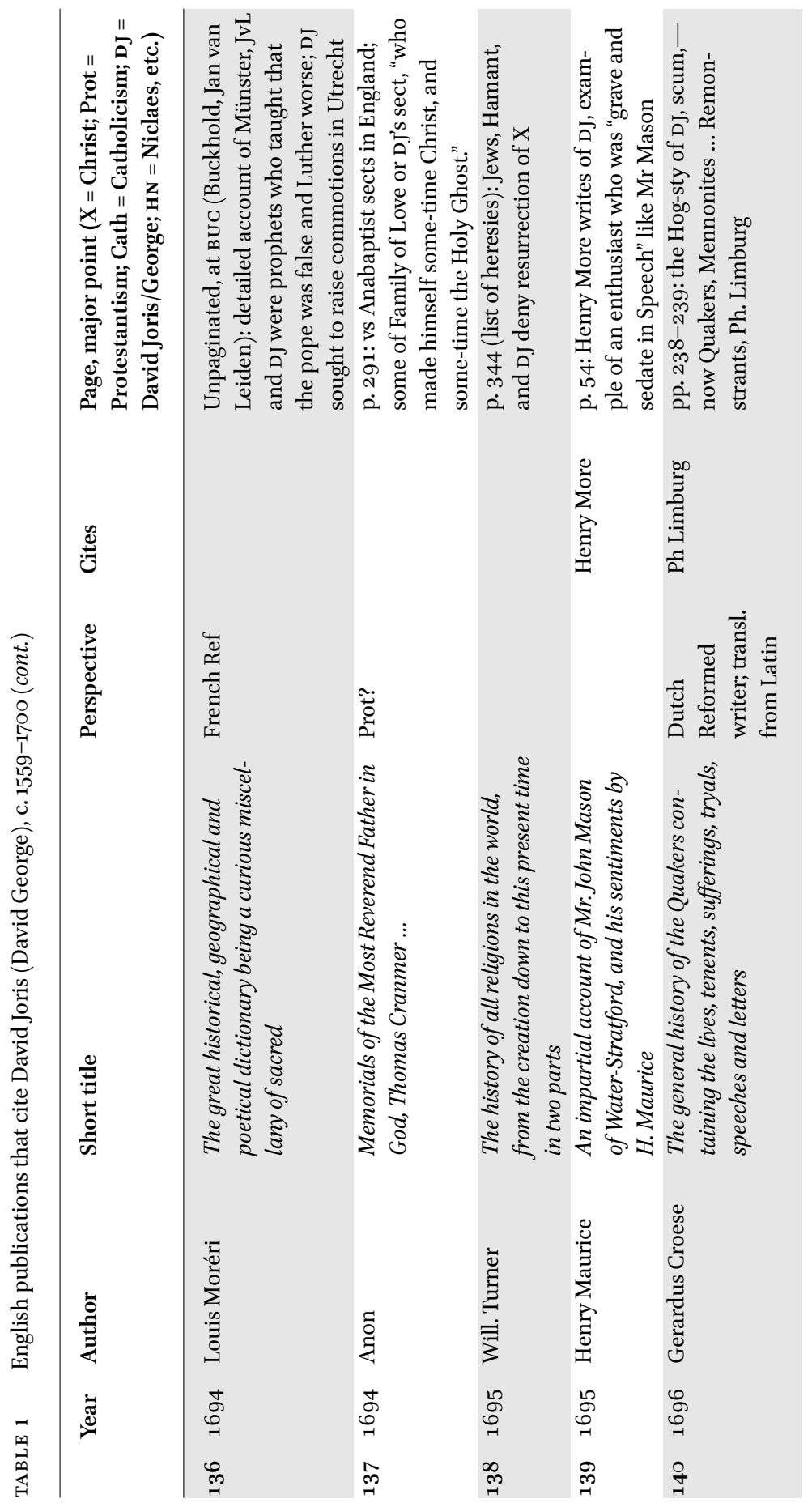




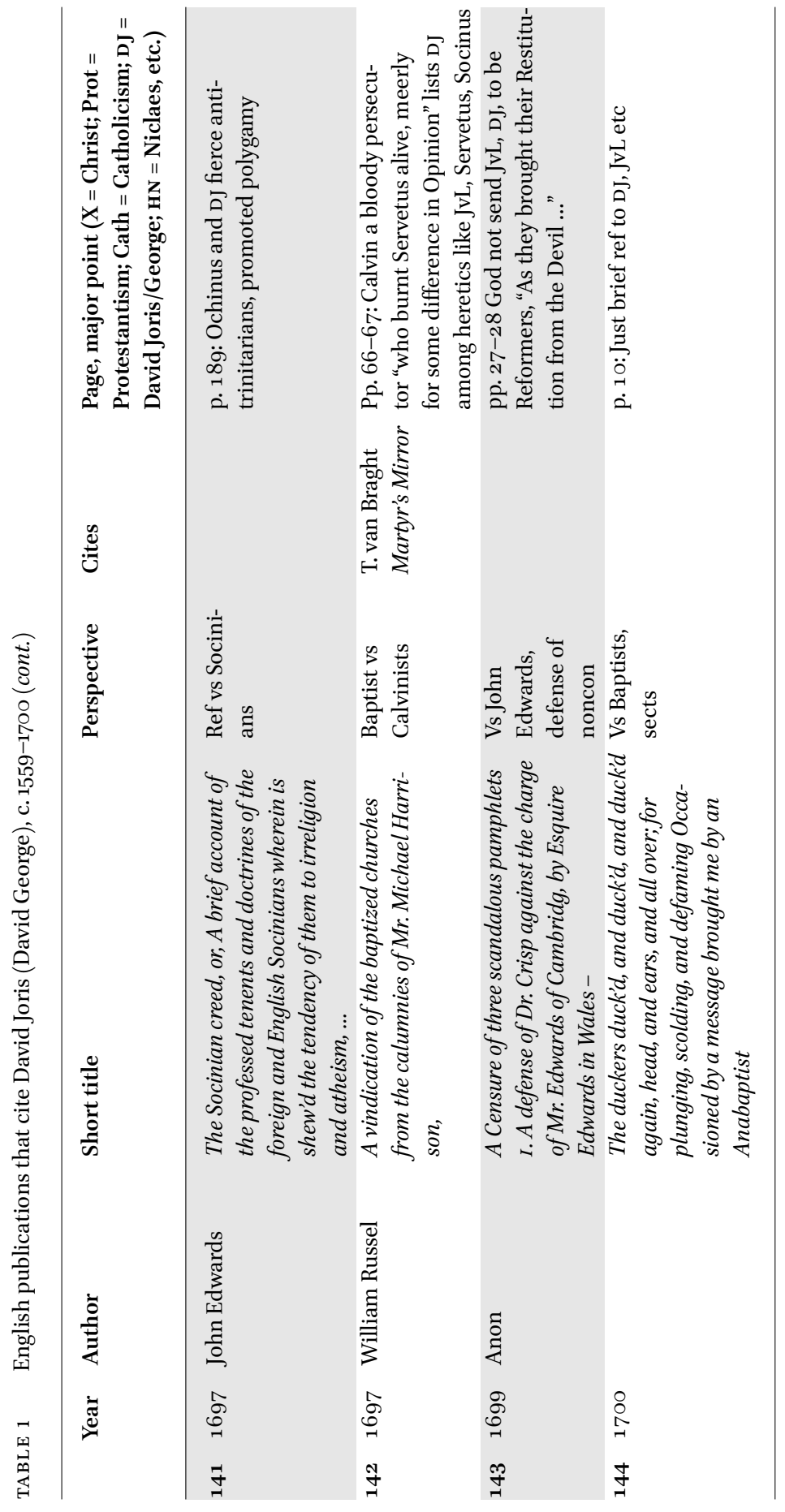




\section{Acknowledgments}

I am deeply grateful to the Social Sciences and Humanities Research Council of Canada and the University of New Brunswick for providing financial support to pursue this research. I am thankful also to the Cambridge University Library's Rare Book Room staff for their wonderful service while I consulted physical copies of many works cited here. Once again it was my privilege to have been visiting Cambridge as a Life Fellow of Clare Hall. 